Article

\title{
An Integrated Decision Support Model Based on BWM and Fuzzy-VIKOR Techniques for Contractor Selection in Construction Projects
}

\author{
Aziz Naghizadeh Vardin ${ }^{1}(\mathbb{D})$, Ramin Ansari ${ }^{1, *(\mathbb{D})}$, Mohammad Khalilzadeh ${ }^{2} \mathbb{D}$, Jurgita Antucheviciene ${ }^{3} \mathbb{D}$ \\ and Romualdas Bausys 4 (D)
}

1 Department of Civil Engineering, Faculty of Technical and Engineering, Imam Khomeini International University, Qazvin 3414896818, Iran; aziz.naghizadeh@gmail.com

2 CENTRUM Católica Graduate Business School, Pontificia Universidad Católica del Perú, Lima 15023, Peru; khalilzadeh@pucp.edu.pe

3 Department of Construction Management and Real Estate, Institute of Sustainable Construction, Vilnius Gediminas Technical University, Sauletekio al. 11, LT-10223 Vilnius, Lithuania; jurgita.antucheviciene@vilniustech.lt

4 Department of Graphical Systems, Vilnius Gediminas Technical University, Sauletekio al. 11, LT-10223 Vilnius, Lithuania; romualdas.bausys@vilniustech.lt

* Correspondence: raminansari@eng.ikiu.ac.ir

check for updates

Citation: Naghizadeh Vardin, A.; Ansari, R.; Khalilzadeh, M.;

Antucheviciene, J.; Bausys, R. An Integrated Decision Support Model Based on BWM and Fuzzy-VIKOR Techniques for Contractor Selection in Construction Projects. Sustainability 2021, 13, 6933

https://doi.org/10.3390/su13126933

Academic Editor: Alberto Giretti

Received: 31 May 2021

Accepted: 17 June 2021

Published: 20 June 2021

Publisher's Note: MDPI stays neutral with regard to jurisdictional claims in published maps and institutional affiliations.

Copyright: (c) 2021 by the authors. Licensee MDPI, Basel, Switzerland. This article is an open access article distributed under the terms and conditions of the Creative Commons Attribution (CC BY) license (https:// creativecommons.org/licenses/by/ $4.0 /)$.

\begin{abstract}
Sustainable development of any country to some extent depends on successful accomplishment of construction projects, particularly infrastructures. Contractors have a key role in the success of these projects. Hence, the selection of a competent contractor as a complicated and hard decision process has a vital importance in the destiny of any construction project. Contractor selection is in essence a multicriteria decision-making that ought to encompass so many aspects of the project and the client's requirements on one hand and the capabilities and past records of the contractors on the other hand. Failure in selecting a competent contractor may cause time and cost overruns; quality shortcomings; increasing in claims, disputes and change orders; and even failure of the project. In spite of deficiencies of selecting a contractor by the rule of "the lowest bid price", it still prevails in many countries including Iran. In this paper, a new contractor selection model based on the best-worst method (BWM) and well-known Fuzzy-VIKOR techniques is proposed as a solution to overcome the deficiencies of the traditional "lowest bid price" rule. An illustrative example of a water channel construction project verified the applicability of the proposed model in practice.
\end{abstract}

Keywords: contractor selection; multicriteria decision-making; best-worst method; fuzzy-VIKOR

\section{Introduction}

In the competitive atmosphere of the contemporary world, success of projects is among the most important goals and objectives of stakeholders in private and public sectors. In fact, attaining the strategic goals of the organization, among other factors, depends on the successful implementation of the projects. One of the most significant factors of a project's success is the selection of a competent contractor [1]. The process of selecting a contractor is a crucial decision which may have serious impacts on the progress and success of a project, and selecting incompetent contractors may have severe consequences [2-4].

Traditionally, deciding on a contractor for a construction project is based on the single criterion of the lowest bid price or so-called "the low bid". In some countries such as Iran, this process is accompanied by a prequalification phase which ensures the client of the qualifications of participating contractors. Despite the fact that unqualified contractors are set aside in the early stages, this does not lead to a quality construction because the winner has no responsibility for a better performance. Previous studies have clearly shown the catastrophic consequences of the traditional approach $[5,6]$. To overcome the deficiencies 
of the traditional approach, in recent decades, researchers and participants of construction industry have employed multicriteria decision making (MCDM) techniques in which, the lowest price criterion is accompanied by other criteria that encompass some other aspects of contractors including past performance, financial strength, technical and managerial capacities, quality control, HSE and so on [2,7]. In some areas, including cultural heritage building renovation, improper contractor selection by means of traditional single criterion method may cause irreparable damages to the sustainability of such buildings. Thus, utilizing multicriteria decision-making methods along with suitable criteria for contractor selection (CS) in these projects are of vital importance [8,9].

Inasmuch as there is a time limitation in tender formalities, there is also a tendency toward methods that are simple to implement, reliable and conceivable to the stakeholders; and able to provide a systematic procedure to prevent bias and subjectivity from entering into the process. The majority of previously proposed models are complicated and time-consuming. With any progress in developing new decision-making techniques, new opportunities and potentials are created for all decision-related problems including CS in the construction sector. In this paper a new integrated model based on the BWM decision-making method as well as the well-known fuzzy VIKOR technique is proposed for CS in Iran.

In every MCDM problem, there are some alternatives that should be scored against some predetermined criteria. In many cases, the importance of the criteria and their weights in the decision process are not equal. Therefore, the derivation of the criteria weights is an important issue in decision-making which is implemented by experts. In many cases, including the CS problem, there are so many criteria that cause several difficulties in straightforwardly determining the weights of the criteria. Taking into account the subjectivity and vagueness of the experts' opinions, this process becomes even more complicated. To help the experts in deriving the criteria's weights, some methods based on pairwise comparisons have been innovated, such as analytic hierarchy process (AHP). These methods provide a systematic approach to the derivation of the criteria's weights, but the consistency of pairwise comparisons is yet a challenging problem. Rezaei [10] declared that the main cause of the inconsistencies is the unstructured way that comparisons are executed in these methods. He proposed a new pairwise comparison-based method called best-worst method (BWM) which uses less comparison data and provides more consistency in the results.

The scores of alternatives (contractors) with respect to the criteria in the CS problem are usually determined by performance data of the contractors. For this reason, there is usually no need for the methods based on pairwise comparisons in the scoring process. On the other hand, there is generally no single contractor who encompasses all the requirements to be selected as the competent alternative. The CS criteria may be of non-commensurable and conflicting nature. So, a compromise solution is preferred as the best selection. The compromise solution is the closest solution to the ideal, and a compromise means an agreement based on mutual concessions [11]. The performance data of contractors may also contain vagueness or uncertainty. VIKOR (Vlsekriterijumska Optimizacija I Kompromisno Resenje) method, which was developed by Opricovic [12], has been known as a powerful tool for MCDM problems with noncommensurable and conflicting criteria in a discrete space of decision-making which compromises ranking of alternatives by maximizing group utility and minimizing individual regret [13]. This method has some advantages over similar methods such as TOPSIS. For instance, a comparison between these two methods shows the more stability of the ranking results in VIKOR than TOPSIS since in the latter a change in evaluation unit of a particular criterion may have an effect on the rankings of the alternatives. The TOPSIS method considers the distances from the ideal point and from the negative-ideal point simultaneously without considering their relative importance, but in the VIKOR method the aggregation index of ranking is based on the distance from the ideal solution which is more compatible with human choice rationale [11]. The Fuzzy extension of this method was developed to consider any vagueness and uncertainty in the decision 
process. Because of the aforementioned reasons the Fuzzy VIKOR method was opted out for final ranking of the alternatives in this paper.

The remainder of this paper is organized as follows. In Section 2, a literature review is presented. In Section 3, the methodology of the study is proposed. In Section 4, the proposed model is applied in an illustrative example, and conclusions are presented in Section 5.

\section{Literature Review}

As mentioned previously, several multicriteria methods have been proposed over the last decades to mitigate the defects of conventional methods in the field of CS.

Alptekin and et al. [2] used a method based on entropy for determining the criteria weights and TOPSIS method for ranking the contractors. Jafari [4] proposed a prequalification model based on the method of quality function deployment (QFD) that takes into account both the requirements of the client or project and contractor's abilities. Darvish and et al. [14] proposed the application of graph theory and matrix methods for considering correlations between different evaluation criteria in the process of the prequalification and ranking contractors.

In the last two decades, the methods based on pairwise comparisons have been used widely by researchers for deriving the criteria weights and ranking purposes. One of the most prevalent methods is AHP and its complicated form, analytical network process (ANP) which have been used in several works. Fong and Choi [15], Al-Harbi [16], Topcu [17], Hadidi and Khater [18], and Chiang and et al. [19] used AHP for both weighting the criteria and ranking purposes. Abdelrahman and et al. [20], Nieto-Morote and Ruz-Vila [21], San Cristobal [22], Polat [23], Taylan and et al. [24], and Morkunaite and et al. [8] utilized AHP technique only for deriving the criteria weights while they used other methods (TOPSIS, VIKOR, PROMETHEE, fuzzy TOPSIS) for ranking the contractors.

Cheng and Li [25] used ANP for both weighting the criteria and ranking the contractors. In some studies, artificial neural network method (ANN) has been used for CS. Khosrowshahi [26] used it in a model for prequalification of contractors. Lam and others used the above-mentioned method in two separate works in different forms. In the second work, they used a fuzzy approach $[27,28]$. El-Sawalhi and others, have used neural network algorithm in combination with genetic and AHP algorithms for prequalification purpose [29]. Hassim et al. [30] also used a fuzzy neural network model for standardization of tender price estimation in Malaysia.

Multiattribute analysis (MAA), multiattribute utility theory (MAUT), cluster analysis (CA), case-based reasoning (CBR), evidential reasoning approach, logistic regression (LR), multivariate discernment technique (MDT), quality-based performance rating (QBPR), data envelopment analysis (DEA), web-based system, COPRAS, MOORA, Hodges-Lehmann rules, ELECTRE TRI, dynamic fuzzy EDAS and support vector machine (SVM) are among other methods that have been used by different researchers over a period of three decades for ranking of alternatives or predicting performance of contractors [31-51].

The summary of the literature review is shown in Tables 1 and 2.

It is clearly seen from the above tables that the most used method is AHP. This is a method based on pairwise comparisons [69]. As mentioned earlier in this paper, the new BWM have some advantages over AHP in terms of the number of pairwise comparisons and also consistency of the results [10]. In CS processes there is often a time limitation and a demand for simplified, yet effective methods or procedures that could be easily understood by stakeholders and participants of the tender process [46]. So, in search of a new systematic, reliable and relatively simple method to replace the traditional method of CS in tenders in Iran, BWM was chosen for weighting the criteria. The previously proposed methods often use complex and time-consuming procedures and suffer from inconsistency of results $[10,69]$. Particularly, the linear model of BWM utilized in this paper provides a straightforward way to obtain the criteria weights without a need for intricate procedures in mathematical modeling or special software knowledge. Although the BWM 
could have also been utilized for ranking purpose, but as a regular practice in tenders the performance data of an alternative with respect to a criterion is usually determined based on the alternative's presented documents, independently of others, so often no comparison is made between the alternatives. Thus, there is less need for a method such as BWM or AHP in the final phase for ranking purpose. On the other hand, because of dealing with conflicting criteria in the CS problems, and the necessity of using a systematic method capable of preventing subjectivity and bias, this paper used the fuzzy-VIKOR method for ranking the alternatives. It should be noted this method has some advantages over similar methods like TOPSIS [11]. VIKOR is a powerful method that its advantages in dealing with the optimization problem of complex systems are now more obvious [13]. As a result, in this paper the BWM method is used in combination with the fuzzy-VIKOR method to take advantage of both methods.z

\subsection{Best-Worst Method}

Pairwise comparisons play a key role in solving MCDM problems and they provide an effective way to extract qualitative information from decision-maker(s). A severe deficiency of this method is the number of pairwise comparisons which a decision-maker has to perform. For instance, in AHP to compare $n$ criteria, at least $n(n-1) / 2$ pairwise comparisons need to be executed by decision-maker [69,70]. Inconsistency of the pairwise comparisons is another significant challenge which usually emerges in practice while executing AHP method [10].

To overcome these defects, in 2015, Jafar Rezaei [10] proposed a new decision-making method named Best-Worst method (BWM), based on pairwise comparisons. Since then, it has found many applications in different areas of study. Mi et al. [70] reviewed different applications of the method from the year 2015 till 2019. In that period, 124 works based on BWM were published, 41 of which are single applications of it. In 40 studies, it was used in combination with another method and in 43 works it was used in combination with more than one other method. One of the most popular applications of BWM is in supply chain management. It was used in many other areas such as production, performance evaluation, aviation industry, energy, transport, education and technology. For instance, recently Amiri et al. [71] used a combination of this method with fuzzy preference programming for determining the criteria importance in the hospital performance evaluation. Chen and Ming [59] used the method for weight determination of criteria in smart product service module. Hendiani et al. [72] proposed a new extension of fuzzy BWM using trapezoidal fuzzy membership functions for sustainable supplier selection purpose.

Rezaei [10] states the main advantages of the BWM over AHP as: (1) the BWM method requires less pairwise comparisons compared to AHP. For instance, to compare $n$ criteria in BWM, a decision-maker only needs to execute $2 n-3$ comparisons, while for AHP $n(n-1) / 2$ comparisons are needed. (2) BWM provides more consistent comparisons and the final results are more reliable than those of AHP. (3) BWM is a vector-based method in which only integers 1-9 are used while in matrix-based methods such as AHP, fractional numbers are also needed and this makes BWM much easier to use.

\subsection{VIKOR Method}

VIKOR Method was developed by Opricovic in 1998 for multicriteria optimization of complex systems in the presence of conflicting criteria and determines compromise solutions for the problem [11]. In the situation of conflicting criteria, a compromise solution is usually preferred over an optimized solution [61]. A fuzzy version of this method was introduced in the year 2011 and is used for solving MCDM problems with conflicting and noncommensurable criteria in the state of uncertainty and lack of precise information [12]. Two recent applications of the VIKOR method for ranking the alternatives are mentioned here: $\mathrm{Li}$ and et al. [73] applied fuzzy VIKOR in a hybrid MCDM model for ranking purpose in the machine tool selection problem. Yue [74] used an extended VIKOR method with group decision-making approach for a software reliability assessment problem. 
Table 1. The related studies in the literature of CS problem (Part A).

\begin{tabular}{|c|c|c|c|c|c|c|c|c|c|c|c|c|c|c|c|c|c|c|c|c|c|c|c|c|c|c|c|c|c|c|}
\hline \multirow[b]{2}{*}{ 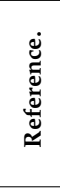 } & \multirow[b]{2}{*}{ Year } & \multicolumn{4}{|c|}{ Values Type } & \multirow{2}{*}{ 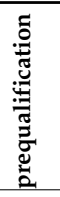 } & \multirow[b]{2}{*}{$\tilde{U}$} & \multirow[b]{2}{*}{$\begin{array}{l}\tilde{y} \\
\dot{b} \\
\bar{n}\end{array}$} & \multirow[b]{2}{*}{$\stackrel{N}{w}$} & \multicolumn{21}{|c|}{ Criteria Importance Determination Method } \\
\hline & & : & $\vec{N}$ & 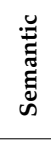 & 点 & & & & & 言 & $\sum_{3}^{\infty}$ & $\begin{array}{l}\frac{\ddot{z}}{2} \\
\frac{\vec{\nu}}{\nu}\end{array}$ & $\hat{z}$ & $\underset{Z}{Z}$ & $\begin{array}{l}\frac{10}{0} \\
\stackrel{0}{0}\end{array}$ & 巳্心 & $\sum_{d}$ & $\begin{array}{l}\hat{a} \\
\text { : } \\
\text { 童 }\end{array}$ & $\begin{array}{l}n \\
\omega \\
0 \\
0 \\
0\end{array}$ & $\stackrel{\infty}{\breve{I}}$ & 点 & $\sum_{0}^{O}$ & 离 & $\begin{array}{l}\tilde{a} \\
\vec{a}\end{array}$ & $\sum_{|r| r}^{n}$ & $\begin{array}{l}\stackrel{I}{\vec{J}} \\
\stackrel{\vec{g}}{\tilde{U}}\end{array}$ & $\stackrel{m}{\underline{g}}$ & 党 & $\stackrel{\approx}{\approx}$ & $\sum_{\infty}^{\infty}$ \\
\hline [52] & 1990 & $\checkmark$ & & & & $\checkmark$ & & & & & & & & & & & $\checkmark$ & & & & & & & & & & & & & \\
\hline [32] & 1994 & $\checkmark$ & & & & $\checkmark$ & $\checkmark$ & & & & & & & & & $\checkmark$ & & & & & & & & & & & & & & \\
\hline [33] & 1996 & $\checkmark$ & & & & $\checkmark$ & & & & & & & & & & & & & & & & & & & & & & & & \\
\hline [53] & 1997 & $\checkmark$ & & & & & $\checkmark$ & & $\checkmark$ & & & & & & & & & & & & & & & & & & $\checkmark$ & & & \\
\hline [15] & 2000 & $\checkmark$ & & & & & $\checkmark$ & & & $\checkmark$ & & & & & & & & & & & & & & & & & & & & \\
\hline [27] & 2000 & $\checkmark$ & & $\checkmark$ & & $\checkmark$ & & & & & & & & $\checkmark$ & & & & & & & & & & & & & & & & \\
\hline [36] & 2001 & $\checkmark$ & & $\checkmark$ & & $\checkmark$ & & & & & & & & & $\checkmark$ & & & & & & & & & & & & & & & \\
\hline [28] & 2001 & $\checkmark$ & & & & $\checkmark$ & & & & & & & & & & & & & & & & & & & & & & & & \\
\hline [16] & 2001 & $\checkmark$ & & & & $\checkmark$ & & & & & & & & & & & & & & & & & $\checkmark$ & & & & & & & \\
\hline [54] & 2002 & $\checkmark$ & & & & $\checkmark$ & $\checkmark$ & & & $\checkmark$ & & $\checkmark$ & & & & & & & & & & & & & & & & & & \\
\hline [37] & 2002 & $\checkmark$ & & $\checkmark$ & & $\checkmark$ & & & & & & & & & & & & & & & & & & & & & & & & \\
\hline$[6]$ & 2002 & $\checkmark$ & & & & 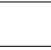 & $\checkmark$ & & & & & & & & & & & & & & & & & & & $\checkmark$ & & & & \\
\hline [17] & 2004 & $\checkmark$ & & & & $\checkmark$ & $\checkmark$ & & & $\checkmark$ & & & & & & & & & & & & & & & & & & & & \\
\hline [25] & 2004 & $\checkmark$ & & & & $\checkmark$ & & & & & & & $\checkmark$ & & & & & & & & & & & & & & & & & \\
\hline [40] & 2004 & $\checkmark$ & & & & & & & $\checkmark$ & & & & & & & & & & & & & & & & & & & & & \\
\hline [42] & 2005 & $\checkmark$ & & & & $\checkmark$ & & & & & & & & & & & & & & & & & & & & & & & & \\
\hline [55] & 2005 & 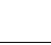 & $\checkmark$ & $\checkmark$ & & 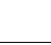 & $\checkmark$ & & & & & & & & & & & & & & $\checkmark$ & & & & & & & & & \\
\hline [41] & 2005 & $\checkmark$ & & & & $\checkmark$ & & & $\checkmark$ & & & & & & & & & & & & & & & & & & & & & \\
\hline [43] & 2005 & $\checkmark$ & & $\checkmark$ & & $\checkmark$ & & & & & & & & & & & & & & & & & & & & & & & & \\
\hline [44] & 2006 & $\checkmark$ & & & & $\checkmark$ & & & & & & & & & & & & & & & & & & & $\checkmark$ & & & & & \\
\hline$[3]$ & 2006 & 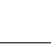 & & & & $\checkmark$ & $\checkmark$ & & & & & & & & & $\checkmark$ & & & & & & & & & & & & & & \\
\hline [45] & 2007 & $\checkmark$ & & & & & $\checkmark$ & & & & & & & & & & & & & & & & & & & $\checkmark$ & & & & \\
\hline [29] & 2007 & $\checkmark$ & & & & $\checkmark$ & & & & $\checkmark$ & & & & & & & & & & & & & & & & & & & & \\
\hline [20] & 2008 & $\checkmark$ & & & & & $\checkmark$ & & & $\checkmark$ & $\checkmark$ & & & & & & & & & & & & & & & & & & & \\
\hline [47] & 2008 & $\checkmark$ & & & & & $\checkmark$ & & & & & & & & & $\checkmark$ & & & & & & & & & & & & & & \\
\hline [56] & 2008 & $\checkmark$ & & $\checkmark$ & & & & & & & & & & & & & & & & & & & & & $\checkmark$ & & & & & \\
\hline
\end{tabular}


Table 1. Cont.

\begin{tabular}{|c|c|c|c|c|c|c|c|c|c|c|c|c|c|c|c|c|c|c|c|c|c|c|c|c|c|c|c|c|c|c|}
\hline \multirow[b]{2}{*}{ 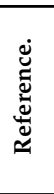 } & \multirow[b]{2}{*}{ Year } & \multicolumn{4}{|c|}{ Values Type } & \multirow{2}{*}{ 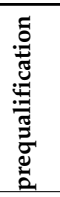 } & \multirow[b]{2}{*}{$y$} & \multirow[b]{2}{*}{$\begin{array}{l}\mathscr{U} \\
\dot{1} \\
\tilde{B}\end{array}$} & \multirow[b]{2}{*}{$\stackrel{N}{\stackrel{N}{U}}$} & \multicolumn{21}{|c|}{ Criteria Importance Determination Method } \\
\hline & & : & $\mathbb{N}_{\mathbb{N}}^{\vec{N}}$ & 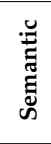 & 点 & & & & & 焉 & $\sum_{3}^{\infty}$ & $\frac{\ddot{z}}{\frac{2}{d}}$ & 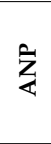 & 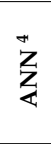 & $\begin{array}{l}\text { ñ } \\
\stackrel{0}{0}\end{array}$ & $\stackrel{\mathscr{u}}{\text { }}$ & $\sum_{a}^{n}$ & 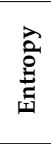 & $\begin{array}{l}n \\
\omega \\
0 \\
0 \\
0\end{array}$ & $\stackrel{\infty}{9}$ & $\stackrel{2}{5}$ & 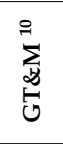 & 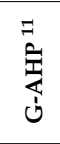 & a & $\sum_{i r \mid}^{\infty}$ & 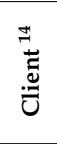 & $\stackrel{\mathscr{2}}{\underline{\oplus}}$ & 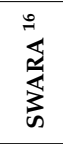 & $\stackrel{\cong}{\cong}$ & $\sum_{n}^{\infty}$ \\
\hline [46] & 2008 & $\checkmark$ & & & & & $\checkmark$ & & & & & & & & & & & & & & & & & & & & & & & \\
\hline [57] & 2009 & & $\checkmark$ & $\checkmark$ & & $\checkmark$ & & & & & & & & & & & & & & & $\checkmark$ & & & & & & & & & \\
\hline [14] & 2009 & $\checkmark$ & & & & $\checkmark$ & $\checkmark$ & & & & & & & & & & & & & & & $\checkmark$ & & & & & & & & \\
\hline [58] & 2009 & & $\checkmark$ & $\checkmark$ & & & $\checkmark$ & & & & & & & & & & & & & & & & & $\checkmark$ & & & & & & \\
\hline [49] & 2010 & $\checkmark$ & & & & $\checkmark$ & & & & & & & & & & & & & & & & & & & & & & & & \\
\hline [22] & 2012 & $\checkmark$ & & & & & $\checkmark$ & & & $\checkmark$ & & & & & & & & & & & & & & & & & & & & \\
\hline [59] & 2012 & $\checkmark$ & & $\checkmark$ & & & $\checkmark$ & & & & & & & & & $\checkmark$ & & & & & & & & & & & & & & \\
\hline [21] & 2012 & & $\checkmark$ & $\checkmark$ & & $\checkmark$ & & & & $\checkmark$ & & & & & & & & & & & $\checkmark$ & & & & & & & & & \\
\hline [60] & 2012 & & $\checkmark$ & $\checkmark$ & & $\checkmark$ & & & & & & & & & & & & & & & $\checkmark$ & & & & & & & & & \\
\hline [61] & 2013 & & $\checkmark$ & $\checkmark$ & & & $\checkmark$ & & & & & & & & & & & & & $\checkmark$ & & & & & & & & & & \\
\hline [4] & 2013 & $\checkmark$ & & & & $\checkmark$ & & & & & & & & & & & & & & & & & & & & & & & & \\
\hline [62] & 2013 & $\checkmark$ & & & & $\checkmark$ & & & & & & & & & & & & & & & & & & & & & & & & \\
\hline [23] & 2016 & $\checkmark$ & & & & & & $\checkmark$ & & $\checkmark$ & & & & & & & & & & & & & & & & & & & & \\
\hline [50] & 2016 & $\checkmark$ & & $\checkmark$ & & & & & $\checkmark$ & & & & & & & & & & & & & & & & & & & & & \\
\hline [63] & 2016 & & $\checkmark$ & $\checkmark$ & & & & $\checkmark$ & & & & & & & & & & & & & $\checkmark$ & & & & & & & & & \\
\hline [19] & 2017 & $\checkmark$ & & & & $\checkmark$ & & & & $\checkmark$ & & & & & & & & & & & & & & & & & & & & \\
\hline [64] & 2017 & $\checkmark$ & & & & $\checkmark$ & $\checkmark$ & & & $\checkmark$ & & & & & & & & & & & & & & & & & & & & \\
\hline [2] & 2017 & $\checkmark$ & & & & & $\checkmark$ & & & & & & & & & & & $\checkmark$ & $\checkmark$ & & & & & & & & & & & \\
\hline [65] & 2017 & & $\checkmark$ & $\checkmark$ & & $\checkmark$ & & & & & & & & & & & & & & $\checkmark$ & & & & & & & & & & \\
\hline [66] & 2018 & $\checkmark$ & & & & & $\checkmark$ & & & $\checkmark$ & & & & & & & & & & & & & & & & & & & & \\
\hline [51] & 2018 & & $\checkmark$ & $\checkmark$ & & & & $\checkmark$ & & & & & & & & $\checkmark$ & & & & $\checkmark$ & & & & & & & & & & \\
\hline [24] & 2018 & $\checkmark$ & $\checkmark$ & $\checkmark$ & & & $\checkmark$ & & $\checkmark$ & $\checkmark$ & & & & & & & & & & & $\checkmark$ & & & & & & & & & \\
\hline [67] & 2018 & & & $\checkmark$ & $\checkmark$ & & $\checkmark$ & & & & & & & & & & & $\checkmark$ & & & & & & & & & & & & \\
\hline$[8]$ & 2019 & $\checkmark$ & & & & & $\checkmark$ & & & $\checkmark$ & & & & & & & & & & & & & & & & & & & & \\
\hline [9] & 2019 & $\checkmark$ & & & & & $\checkmark$ & & & $\checkmark$ & & & & & & & & & & & & & & & & & & $\checkmark$ & & \\
\hline
\end{tabular}


Table 1. Cont.

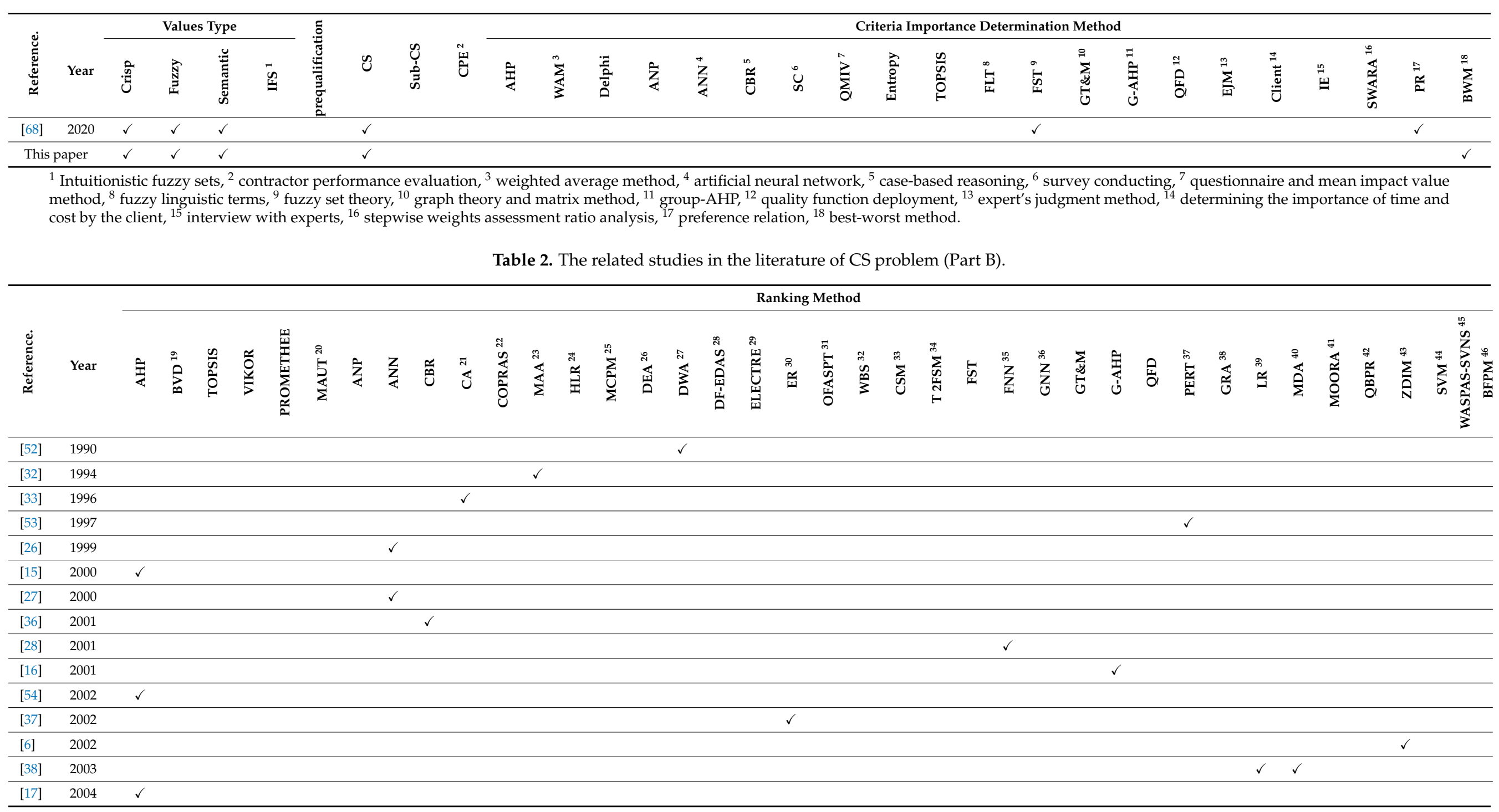


Table 2. Cont

Ranking Method

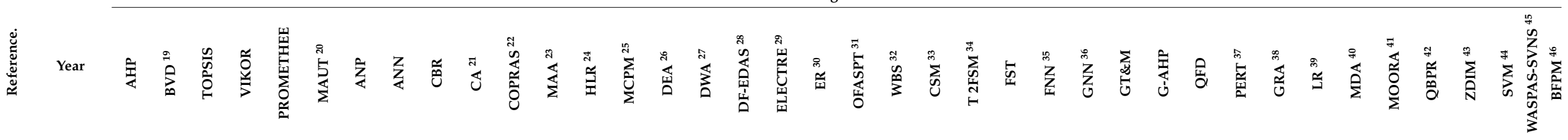

[25] 2004

\begin{tabular}{ll} 
[40] & 2004 \\
\hline$[42]$ & 2005
\end{tabular}

[55] 2005

\begin{tabular}{ll}
\hline [41] 2005 \\
\hline
\end{tabular}

\begin{tabular}{ll}
\hline 433$]$ & 2005
\end{tabular}

[44] 2006

[3] 2006

\begin{tabular}{ll}
\hline [45] & 2007 \\
\hline$[29]$ & 2007
\end{tabular}

[20] 2008

\begin{tabular}{ll}
{$[47] \quad 2008$} \\
\hline$[56]$ & 2008
\end{tabular}

[56] 2008

[46] 2008

\begin{tabular}{ll}
\hline$[57]$ & 2009 \\
\hline$[14]$ & 2009
\end{tabular}

[58] 2009

[48] 2009

[49] 2010

[22] 2012

[59] 2012

[21] 2012

[60] 2012

[61] 2013

[4] 2013

[62] 2013 
Table 2. Cont.

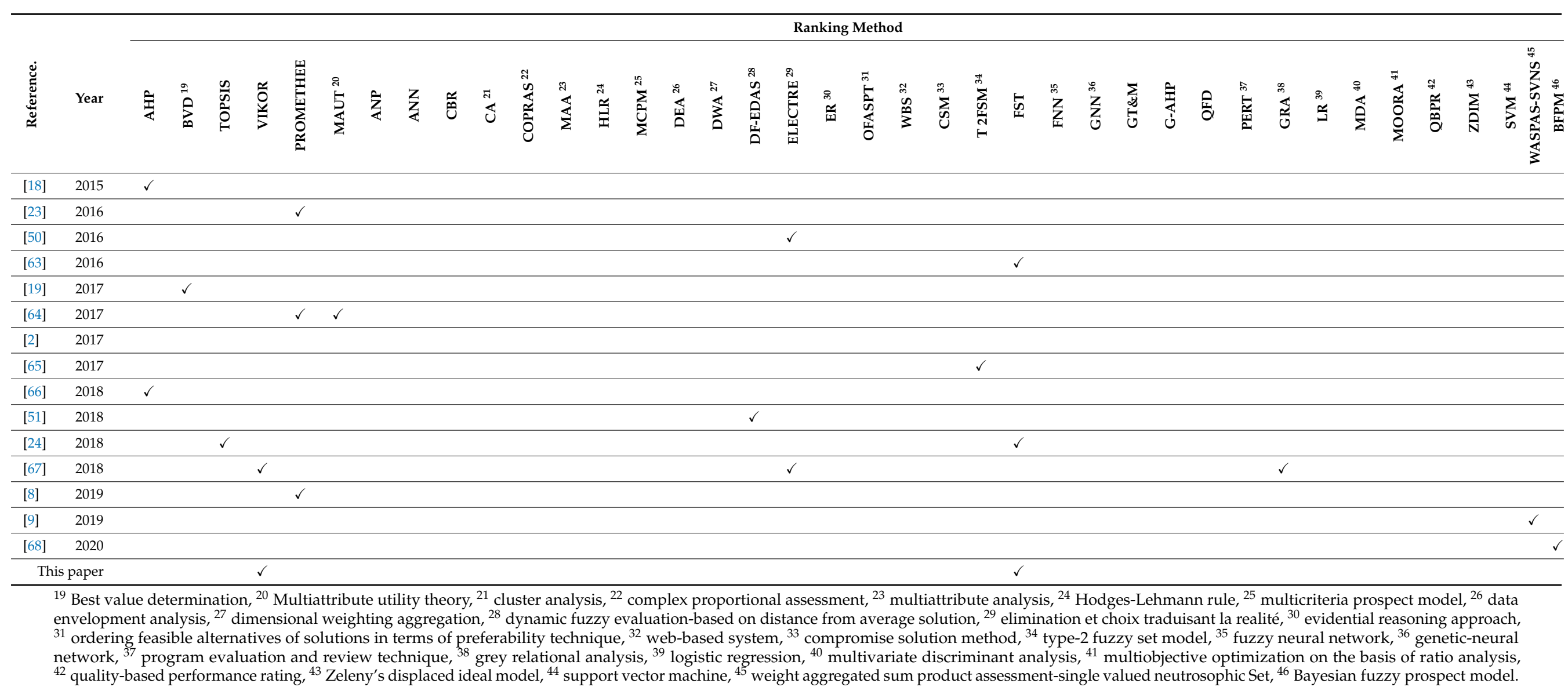


VIKOR method has also been used in various works for CS. Cristobal [22] used it in a case study of CS for a road building project in Spain. Hashemi et al. utilized an integrated approach of this method, including ELECTRE, VIKOR, intuitionistic fuzzy sets (IFS) and Grey relational analysis (GRA) for ranking the alternatives in CS process [67]. According to Khoso et al. [75] the VIKOR method has been applied more frequently in combination as a hybrid decision-making method than other methods in CS studies, followed by the fuzzy AHP method.

\subsection{Fuzzy Set Theory}

In the traditional methods, modeling of a problem is based on crisp, deterministic and precise reasoning and calculations. In the reality, however, not only in many cases the real situation cannot be described precisely in a crisp and deterministic way, but also explanation of a real system often requires so much information and data that the human mind is not able to detect, process and fully understand them [76].

Real situations may be uncertain or vague in several ways. One kind of uncertainty is related to lack of information about the future state of a system. This type of uncertainty is the scope of probability and statistics theories. Another kind of uncertainty is related to semantic description of events or propositions that is known as fuzziness. This kind of vagueness and uncertainty is found in all areas of knowledge in which human judgment, speculation and decisions are important. Among these areas is decision-making, reasoning, learning and so on [76].

Some of the sources of uncertainty in the field of CS are as follows [77]:

- Lack of sufficient information about competencies of contractors so that experts are obliged in some cases to surmise about them.

- Ambiguousness of the decision-maker about his understanding of the selection process.

- Complexity, lack of clarity, or incompleteness in project's specifications which makes it hard for experts to decide on the sufficiency of contractors' skills and capabilities for construction of the project.

- Uncertainty in the project's information: the complete information is utilized by experts or decision-makers whereas incomplete information has yet to be processed.

- Indeterminate conditions of companies: strengths and weaknesses of companies, alongside with the lack of credible information about their abilities, makes it hard for the decision-makers to state their views quantitatively with respect to project criteria.

One way to deal with uncertainties is utilizing several criteria and assigning different weights to them. In order to facilitate the application of the experts' opinions in the process of calculations, fuzzy methods are used to change the linguistic qualitative opinions to numerical quantities [77].

Fuzzy set theory was introduced by Prof. L. A. Zadeh $(1965)$ and Goguen $(1967,1969)$. They generalized the classic concepts of a set and proposition to encompass the abovementioned fuzziness. This theory provides a natural method to encounter the problems in which the source of imprecision is vagueness or lack of precisely defined attributes for determining the dependency of a thing to a category or class, and not the existence of random or accidental variables [76].

Triangular and trapezoidal fuzzy numbers are special types of fuzzy sets which are used widely in different types of decision-making problems [78]. In this paper, triangular fuzzy numbers are used. 
Definition 1. Triangular fuzzy number. Fuzzy number ã is defined as a triangular fuzzy number (TFN) if its membership function is as follows [79]:

$$
\mu_{\widetilde{a}}(x)= \begin{cases}0, & x<l \\ \frac{x-l}{m-l}, & l \leq x<m \\ \frac{u-x}{u-m}, & m \leq x \leq u \\ 0, & x>u\end{cases}
$$

In which, $l, m$, and $u$ are respectively lower, modal and upper values of the support of $\tilde{a}$.

So, a triangular number can be represented as a triplet $(1, \mathrm{~m}, \mathrm{u})$. Membership function of fuzzy number ã is illustrated in Figure 1.

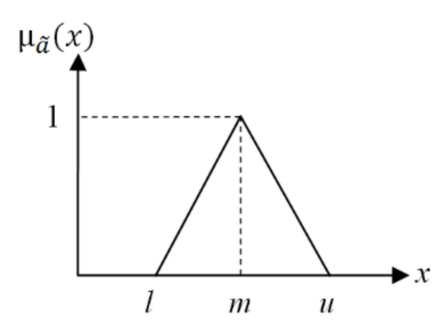

Figure 1. Membership function of a TFN.

Basic operations on fuzzy numbers are performed according to following rules. If $\widetilde{a}=\left(a_{l}, a_{m}, a_{u}\right)$ and $\widetilde{b}=\left(b_{l}, b_{m}, b_{u}\right)$ are two fuzzy numbers, then [51,80]:

$$
\begin{gathered}
\widetilde{a} \oplus \widetilde{b}=\left(a_{l}+b_{l}, a_{m}+b_{m}, a_{u}+b_{u}\right) \\
\widetilde{a} \ominus \widetilde{b}=\left(a_{l}-b_{u}, a_{m}-b_{m}, a_{u}-b_{l}\right) \\
\widetilde{a} \otimes \widetilde{b}=\left(a_{l} b_{l}, a_{m} b_{m}, a_{u} b_{u}\right) \\
\widetilde{a} \oslash \widetilde{b}=\left(a_{l} / b_{u}, a_{m} / b_{m}, a_{u} / b_{l}\right) \\
\forall \lambda>0, \lambda \in R: \lambda \widetilde{a}=\left(\lambda a_{l}, \lambda a_{m}, \lambda a_{u}\right) \\
\forall \lambda>0, \lambda \in R: \lambda \widetilde{a}=\left(\lambda a_{l}, \lambda a_{m}, \lambda a_{u}\right) \\
\forall \lambda<0, \lambda \in R: \lambda \widetilde{a}=\left(\lambda a_{u}, \lambda a_{m}, \lambda a_{l}\right)
\end{gathered}
$$

For some other operations, the reader can refer to [12].

In some cases, there is a need to change a fuzzy number to a crisp value; an operation which is known as defuzzification of a fuzzy number. There are several methods for defuzzification [81]. In this paper the method known as second weighted mean is used for this purpose.

Definition 2. If $\widetilde{a}=\left(a_{l}, a_{m}, a_{u}\right)$ be a fuzzy number, defuzzification of it according to the rule of second weighted mean gives its crisp value as:

$$
\operatorname{Crisp}(\widetilde{a})=\frac{a_{l}+2 a_{m}+a_{u}}{4}
$$

Prof. L. A. Zadeh introduced linguistic variables that are usually used for expressing performances of qualitative attributes [82]. A linguistic variable is one that is stated by means of words or phrases of a natural or artificial language, and may take on effective values such as, "very good", "good", "medium", "fair", "poor" and etc. [81]. Qualitative evaluations by experts in an uncertain environment by means of linguistic variables may 
be quantified by fuzzy numbers. Hence, in studies based on fuzzy concepts, the equivalent fuzzy number of each linguistic variable is often determined in advance.

\section{Methodology}

In tenders, every contractor comes to the competition ground with different capabilities, abilities, past performances, and attitudes to take on the responsibility of a construction project. So, it is impossible in many cases to find a contractor who could absolutely satisfy the project and the client's requirements. There are many criteria which the performance of each contractor should be measured with respect to them and in general no single contractor may come up with the best performances in all criteria. So, the selection of a contractor for a project is in essence a MCDM.

MCDM is a branch of operations research [83]. Despite the complexity of MCDM methods, they have quite simple parts. These parts are alternatives, solutions or measures, at least two attributes or criteria and at least one decision maker.

The methodology of this study has three general phases:

Phase 1 Introduction of the problem: in this phase, alternatives and the criteria for contractor assessment are determined.

Phase 2 Weighting: in this phase, the weight or influence of the members of the decisionmaking group and the weights of assessment criteria are determined.

Phase 3 Ranking: in this phase, the performances of alternatives with respect to each criterion are determined and then, final ranks of alternatives are specified.

In the first phase, assessment criteria are defined and their hierarchical structure is established. This may be followed by a screening step in which a concise list of criteria is provided. Then the members of the decision-making group are specified and next, alternatives (contractors) are determined. The second phase includes determining decisionmakers' weights or degree of their influence in the decision process, deriving the main criteria weights by means of BWM for each decision maker and then, calculating group weights as the weighted average of individual weights. The same procedure is followed to obtain the local weights of subcriteria. Knowing the main criteria weights and the local weights of the subcriteria, it is possible to calculate the global weights of the subcriteria. In the third phase, at first, a linguistic scale is defined for evaluating contractors' performances on qualitative criteria, then, contractors' performances are evaluated by means of accessible data for quantitative criteria or surveying the decision-makers on qualitative criteria. After that, the decision matrix is established and finally, ranking of alternatives is determined by fuzzy-VIKOR method. The flowchart in Figure 2 illustrates the algorithm of the proposed model. In the successive subsections, brief descriptions of the utilized methods are given.

\subsection{Best-Worst Method (BWM)}

The original version of this method uses a nonlinear mathematical model for obtaining the optimal weights. In the case of more than three criteria, this model gives multiple solutions. The linear model of this technique which was proposed later, delivers unique solutions even in the case of more than three criteria [84]. Since in tenders or in the process of prequalifying contractors, the weights of criteria should be determined uniquely by decision-makers prior to inviting contractors for competition, so, in this paper we took advantage of the linear version in the proposed model. It is worth mentioning at this point that although it was possible to use BWM for ranking, but since the performances of alternatives (contractors) are evaluated independently and pairwise comparisons of them is not needed, another technique was chosen for ranking purpose.

The steps of linear model of BWM are as follows:

Step 1. Determine the set of decision criteria.

Step 2. Determine the best and the worst criteria.

Step 3. Determine preferences of the best criterion over all other criteria, using a number between 1 and 9, and establish the best-to-others vector. The elements of this vector denoted by $a_{B j}$, represents the importance of the best criterion over criterion $j$. 
Step 4. Determine preferences of all other criteria over the worst criterion using an integer of 1 to 9 and establish the others-to-worst vector, elements of which are denoted by $a_{j W}$ that represents the importance of criterion $j$ over the worst criterion.

Step 5. Find optimized weights $\left(w^{*} 1, w^{*}{ }_{2}, \ldots, w^{*}\right)$ and $\xi^{L^{*}}$ by solving the following linear model:

$\min \xi^{L}$ s.t. $\left|w_{B}-a_{B j} w_{j}\right| \leq \xi^{L}$, for all $j\left|w_{j}-a_{j W} w_{W}\right| \leq \xi^{L}$, for all $j \sum_{j} w_{j}=1 w_{j} \geq 0$, for all $j$

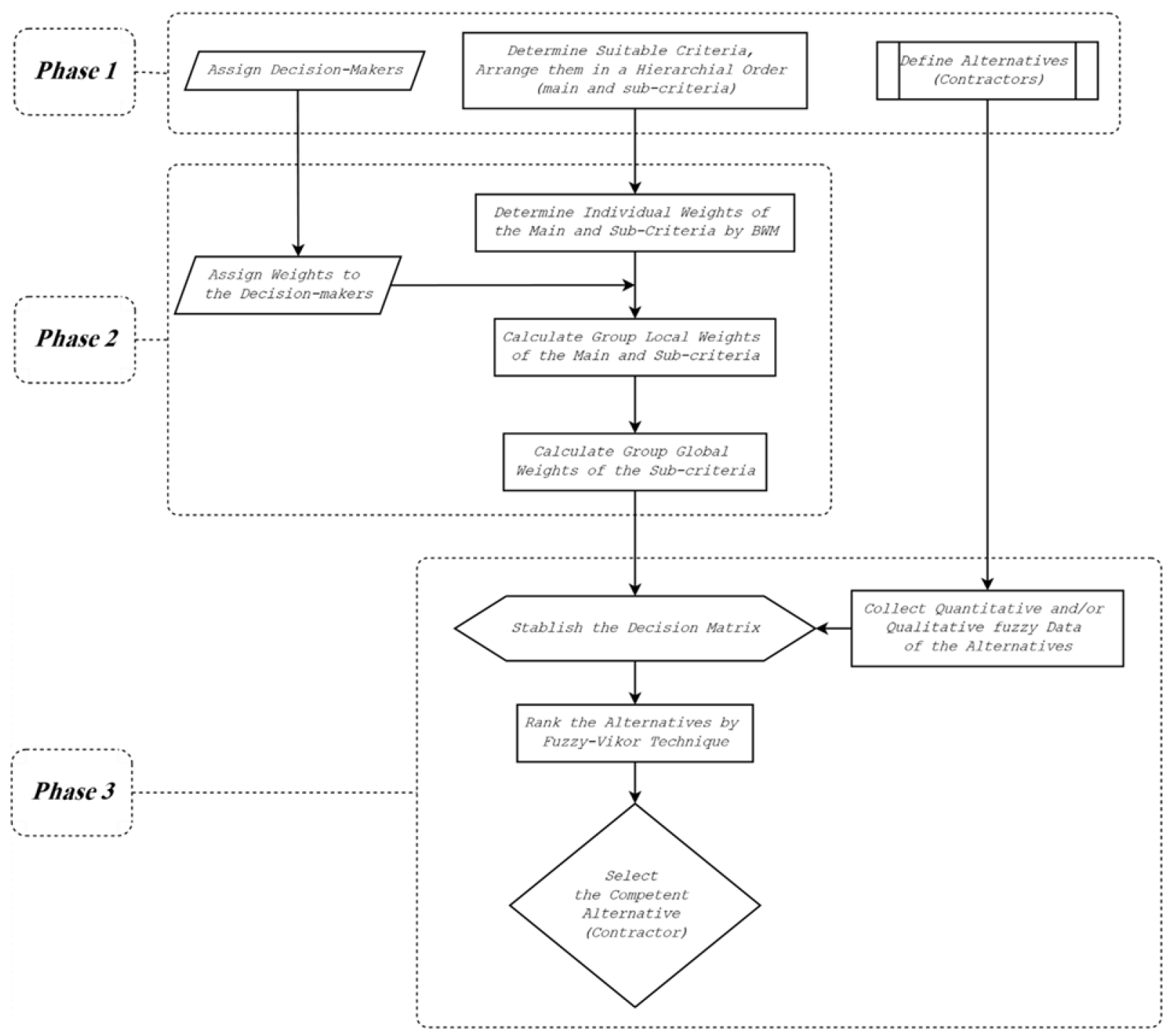

Figure 2. Flowchart of the proposed model.

In the linear model of the BWM, $\xi^{L^{*}}$ is considered as an indicator of pairwise comparisons' consistency: a value nearer to zero is a sign of high level of consistency [84]. However, as an effective way to address the consistency problem in this model, Liang et al. [85] recently proposed a method based on input data, known as input-based method. In this method, after determining the preferences of the criteria by a decision-maker in the form of best-to-others and others-to-worst vectors, an immediate feedback on the consistency of her/his data is provided. It is required the preferences to be corrected before going on the implementation of the model, if the consistency ratios are not in the allowable threshold. 
Definition 3. Input-based consistency ratio is defined as:

$$
C R^{I}=\max _{j} C R_{j}^{I}
$$

where,

$$
C R_{j}^{I}= \begin{cases}\frac{\left|a_{B j} \times a_{j W}-a_{B W}\right|}{a_{B W} \times a_{B W}-a_{B W}} & a_{B W}>1 \\ 0 & a_{B W}=1\end{cases}
$$

In the above relations, $C R^{I}$ is the global input-based consistency ratio for all criteria and $C R_{j}^{I}$ is the indicator of local consistency level for the criterion $C_{j}$ [85]. Allowable thresholds of input-based consistency ratio are obtained from Table 3 of [85] with respect to the number of criteria and the scale used in the BWM (Table 3).

Table 3. Allowable thresholds for input-based consistency ratio [85].

\begin{tabular}{cccccccc}
\hline \multirow{2}{*}{ Scale } & \multicolumn{7}{c}{ Criteria Number } \\
\cline { 2 - 8 } & $\mathbf{3}$ & $\mathbf{4}$ & $\mathbf{5}$ & $\mathbf{6}$ & $\mathbf{7}$ & $\mathbf{8}$ & $\mathbf{9}$ \\
\hline 3 & 0.1667 & 0.1667 & 0.1667 & 0.1667 & 0.1667 & 0.1667 & 0.1667 \\
4 & 0.1121 & 0.1529 & 0.1898 & 0.2206 & 0.2527 & 0.2577 & 0.2683 \\
5 & 0.1354 & 0.1994 & 0.2306 & 0.2546 & 0.2716 & 0.2844 & 0.2960 \\
6 & 0.1330 & 0.1990 & 0.2643 & 0.3044 & 0.3144 & 0.3221 & 0.3262 \\
7 & 0.1294 & 0.2457 & 0.2819 & 0.3029 & 0.3144 & 0.3251 & 0.3403 \\
8 & 0.1309 & 0.2521 & 0.2958 & 0.3154 & 0.3408 & 0.3620 & 0.3657 \\
9 & 0.1359 & 0.2681 & 0.3062 & 0.3337 & 0.3517 & 0.3620 & 0.3662 \\
\hline
\end{tabular}

Number of Decision-Makers

According to Saaty and et al. [86] the number of experts or decision-makers for judging the preferences in pairwise comparison-based methods does not obey statistical rules of sample size; on the contrary, they are selected according to their knowledge, experience and so on. In fact, if a judge is experienced in an area, the participation of others who may not be as good would dilute his accuracy. The judges may also be assigned weights that make the judgments of a high weight judge count more than those with lower weight [86]. In tenders in the public sector a committee of three authorized people is usually assigned by the administrative organization of the client to make decisions. In the private sector, however, the number of decision-makers may be limited to the number of the company's shareholders.

\subsection{Fuzzy-VIKOR Method}

VIKOR method utilizes a compromise solution for ranking a set of alternatives in the case of existing conflicting criteria. This method utilizes a special measure called "nearness to ideal solution" for ranking the alternatives [11]. In the state of conflicting criteria, compromise solution is preferred to an optimized one [61]. The Fuzzy VIKOR method was also developed from the original nonfuzzy VIKOR method to solve MCDM problems with conflicting and noncommensurable criteria in uncertainty conditions [12]. In this method, both alternatives' performances and the criteria weights may be fuzzy sets and TFNs are utilized to indicate imprecise numerical quantities. Suppose that $\widetilde{x}_{i j}=\left(l_{i j}, m_{i j}, u_{i j}\right)$ is the fuzzy number indicating the performance evaluation of alternative $A_{i}$ with respect to criterion $C_{j}$. Then, the steps of this method can be summarized as follows:

Step 1. Determine the best and the worst fuzzy values for each criterion, and denote them respectively by $\tilde{f}_{j}^{+}=\left(l_{j}^{+}, m_{j}^{+}, u_{j}^{+}\right)$and $\widetilde{f}_{j}^{-}=\left(l_{j}^{-}, m_{j}^{-}, u_{j}^{-}\right)$for all $j=1,2, \ldots, n$. If the criterion is positive or benefit one, then,

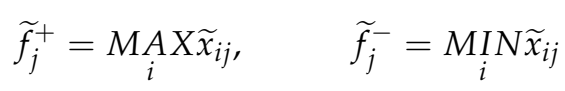


and if the criterion is a cost or negative one, then,

$$
\widetilde{f}_{j}^{+}=\underset{i}{\operatorname{IN}} \widetilde{x}_{i j}, \quad \widetilde{f}_{j}^{-}=\underset{i}{\operatorname{AXX} \widetilde{x}_{i j}}
$$

Step 2. Calculate fuzzy normalized differences, $\widetilde{d}_{i j}, i=1, \ldots, m, j=1, \ldots, n$ as:

$$
\begin{aligned}
\widetilde{d}_{i j} & =\left(\widetilde{f}_{j}^{+} \ominus \widetilde{x}_{i j}\right) /\left(u_{j}^{+}-l_{j}^{-}\right) \text {(for positive or benefit criteria) } \\
\widetilde{d}_{i j} & =\left(\widetilde{x}_{i j} \ominus \widetilde{f}_{j}^{+}\right) /\left(u_{j}^{-}-l_{j}^{+}\right)(\text {for negative to cost criteria) }
\end{aligned}
$$

Step 3. Calculate $\widetilde{S}_{i}=\left(S_{i}^{l}, S_{i}^{m}, S_{i}^{u}\right)$ and $\widetilde{R}_{i}=\left(R_{i}^{l}, R_{i}^{m}, R_{i}^{u}\right)$ for all alternative $(I=1, \ldots, m)$ as:

$$
\begin{aligned}
& \widetilde{S}_{i}=\sum_{j=1}^{n} \oplus\left(\widetilde{w}_{j} \otimes \widetilde{d}_{i j}\right) \\
& \widetilde{R}_{i}=\operatorname{MAX}_{j}\left(\widetilde{w}_{j} \otimes \widetilde{d}_{i j}\right)
\end{aligned}
$$

where $\widetilde{S}$ and $\widetilde{R}$ are respectively fuzzy weighted sum and fuzzy maximum operation, and $\widetilde{w}_{j}$ is fuzzy weights of criteria.

Step 4. Calculate $\widetilde{Q}_{i}=\left(Q_{i}^{l}, Q_{i}^{m}, Q_{i}^{u}\right)$ values for all alternatives as:

$$
\widetilde{Q}_{i}=\frac{v\left(\widetilde{S}_{i} \ominus \widetilde{S}^{*}\right)}{S^{\circ u}-S^{* l}} \oplus \frac{(1-v)\left(\widetilde{R}_{i} \ominus \widetilde{R}^{*}\right)}{R^{\circ u}-R^{* l}}
$$

where,

$$
\begin{aligned}
\widetilde{S}^{*}=\operatorname{MIN}_{i} \widetilde{S}_{i}, & S^{\circ u}=\max _{i} S_{i}^{u} \\
\widetilde{R}^{*}=\operatorname{MIN}_{i} \widetilde{R}_{i}, & R^{\circ u}=\max _{i} R_{i}^{u}
\end{aligned}
$$

$v$ is defined as a weight for the strategy of the majority of criteria and so $(1-v)$ is the weight of the individual regret. By setting $v=0.5$, a compromise between these two strategies is reached.

Step 5. Defuzzify the values, $\widetilde{S}_{i}, \widetilde{R}_{i}$, and $\widetilde{Q}_{i}$ by the rule of second weighted mean according to Equation (9) and obtain crisp values, $S, R$, and $Q$.

Step 6. Rank the alternative by sorting out crisp values $S, R$, and $Q$ and prepare three lists of ranking.

Step 7. Determine an alternative as a compromise solution with the best value (minimum) of $Q$ provided that these two conditions are satisfied:

Condition 1. "Acceptable advantage".

$$
A d v \geq D Q
$$

where,

$$
\begin{gathered}
A d v=\left[Q\left(A^{\prime \prime}\right)-Q\left(A^{\prime}\right)\right] /\left[Q\left(A^{(m)}\right)-Q\left(A^{\prime}\right)\right] \\
D Q=1 /(m-1)
\end{gathered}
$$

and $A^{\prime}, A^{\prime \prime}$ and $A^{(m)}$ are respectively the alternatives with the first, second and last rankings in the $Q$-list. $D Q$ is 0.25 for values of $m$ not more than $4[87,88]$.

Condition 2. "Acceptable stability in decision-making".

The alternative $A^{\prime}$ must also be the best (minimum) in $S$ or/and $R$ lists.

If one of the conditions is not satisfied, some of alternatives may constitute a set of compromise solutions as follow: 
- Alternative $A^{\prime}$ and $A^{\prime \prime}$ if only Condition 2 is not satisfied.

- Alternatives $A^{\prime}, A^{\prime \prime}, \ldots, A^{(H)}$, if Condition 1 is not satisfied, where $A^{(H)}$ is the last alternative with which Condition 1 is not satisfied i.e., $Q\left(A^{(H)}\right)-Q\left(A^{\prime}\right)<D Q$ for maximum $H$.

\section{Illustrative Example}

In this section, the CS process of a past project is recreated to show the applicability of the proposed model in a real case as an illustrative example. Because of legal limitations, it was not possible to implement the proposed model in an ongoing real project's tender process. The project under consideration is a portion of a water channel construction project in Iran. The project was designed to convey water from a dam on Aras River in northwest Iran to southern regions. The project was awarded to a contractor by the design-bid-build (DBB) method some years ago. At the time, a prequalification phase was implemented before selecting the contractor by the least price bid rule according to the tender law in Iran. In this stage, a total of 9 out of 20 contractors could pass the prequalification phase. Some of them withdraw from the tender and in the final phase only four contractors remained. To protect the contractor's privacy, the exact title of the project and the names of contractors are concealed throughout the paper. We denote the contractors (alternatives) by A, B, C and $\mathrm{D}$. According to the tender documents, their proposed bid prices were as shown in Table 4. Obviously, the contractor $\mathrm{C}$ had been selected according to the tender law. At the time of the study, the project had undergone both time and cost overruns but the degree of the parties' liability for these overruns was not known yet.

Table 4. Bid price of the contractors in the tender.

\begin{tabular}{cc}
\hline Alternative & Bid Price (Rials) \\
\hline A & $782,000,000,000$ \\
B & $1,077,195,211,299$ \\
C & $717,135,210,855$ \\
D & $823,639,532,214$ \\
\hline
\end{tabular}

\subsection{Criteria}

For comparing the results of this study with the results of original tender, we basically used the criteria and the scoring system which are common in the prequalification phase in Iran, and "the least bid price" was added just as a criterion among others. In order to check the model completeness in dealing with fuzziness in some data, we added some important criteria with fuzzy characteristics. The hierarchy of the main criteria and subcriteria that was utilized in the illustrative example is illustrated in Figure 3.

\subsection{Criteria Weights}

For determining the criteria weights, the opinions of decision-makers were obtained via a questionnaire survey. Each of the three decision-makers gave their opinions about the preferences of the main criteria (MC1 to MC6) and subcriteria (sc01 to sc04) and (sc05 to sc09) separately (Tables 5-7). Inconsistency of input data was calculated according to relation (12). Red numbers show the inconsistent data.

Inconsistency of input data should be adjusted before entering them in the BWM model. So, referring to decision makers, inconsistent data was discussed with them and necessary adjustments carried out. The results are illustrated in Tables 8-10. 


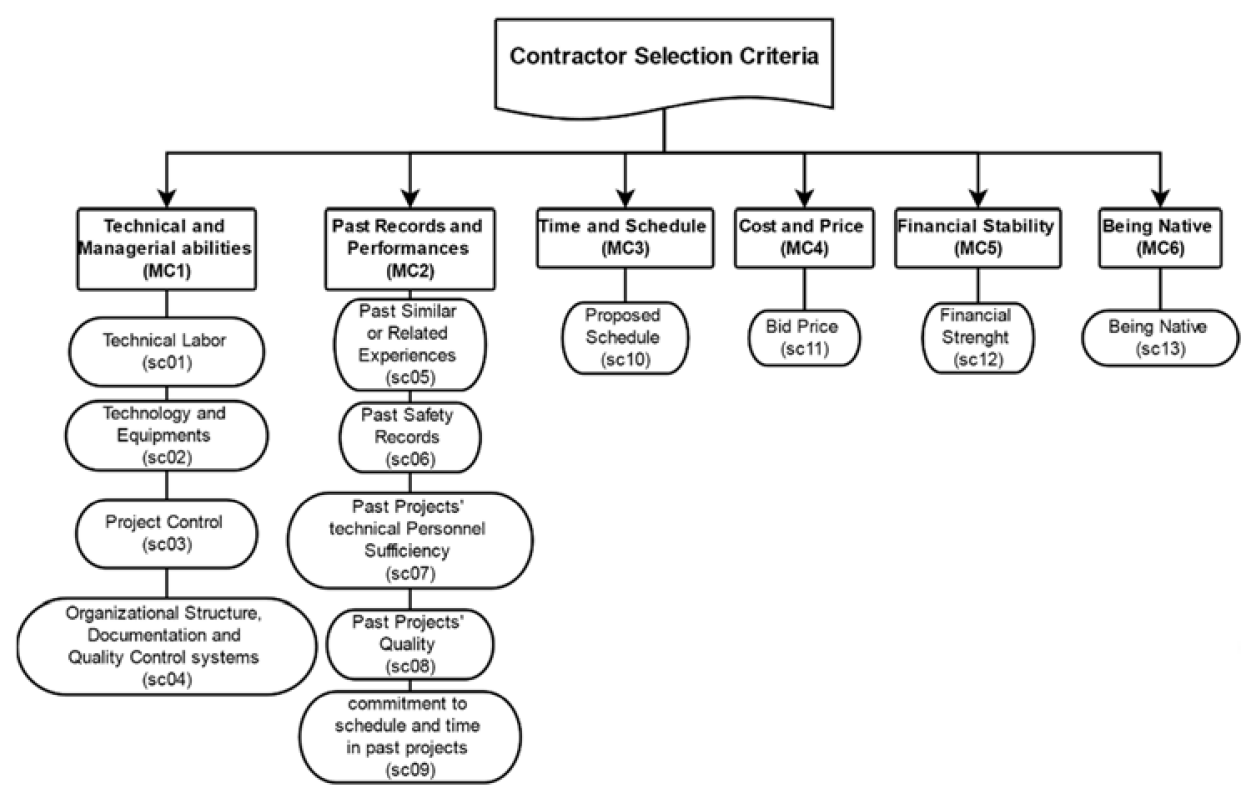

Figure 3. Criteria hierarchy in the illustrative example.

Table 5. Best-to-others and others-to-worst vectors for main criteria.

\begin{tabular}{|c|c|c|c|c|c|c|c|c|}
\hline \multirow[t]{2}{*}{ Decision-Maker } & \multicolumn{8}{|c|}{ Preference of the Best Criterion over Others } \\
\hline & $\begin{array}{c}\text { Best } \\
\text { Criterion }\end{array}$ & MC1 & MC2 & MC3 & MC4 & MC5 & MC6 & \\
\hline DM01 & MC2 & 2 & 1 & 7 & 3 & 4 & 8 & \\
\hline DM02 & MC2 & 2 & 1 & 6 & 6 & 7 & 9 & \\
\hline \multirow[t]{3}{*}{ DM03 } & MC2 & 2 & 1 & 5 & 4 & 3 & 5 & \\
\hline & \multicolumn{8}{|c|}{ Preference of Other Criteria over the Worst Criterion } \\
\hline & $\begin{array}{l}\text { Worst } \\
\text { Criterion }\end{array}$ & MC1 & MC2 & MC3 & MC4 & MC5 & MC6 & \\
\hline DM01 & MC6 & 9 & 9 & 5 & 6 & 7 & 1 & \\
\hline DM02 & MC6 & 9 & 9 & 4 & 5 & 8 & 1 & \\
\hline DM03 & MC6 & 4 & 5 & 2 & 3 & 3 & 1 & threshold \\
\hline DM01 & & 0.1786 & 0.0179 & 0.4821 & 0.1786 & 0.3571 & 0.0000 & \\
\hline DM02 & $C R_{j}^{I}$ & 0.1250 & 0.0000 & 0.2083 & 0.2917 & 0.6528 & 0.0000 & 0.3337 \\
\hline DM03 & & 0.1500 & 0.0000 & 0.2500 & 0.3500 & 0.2000 & 0.0000 & \\
\hline
\end{tabular}

Table 6. Best-to-others and others-to-worst vectors for subcriteria sc01 to sc04.

\begin{tabular}{|c|c|c|c|c|c|c|}
\hline \multirow[t]{2}{*}{ Decision-Maker } & \multicolumn{6}{|c|}{ Preference of the Best Criterion over Others } \\
\hline & Best Criterion & sc01 & $\mathrm{sc} 02$ & $\mathrm{sc} 03$ & sc04 & \\
\hline DM01 & $\mathrm{sc} 02$ & 1 & 1 & 3 & 2 & \\
\hline DM02 & sc01 & 1 & 3 & 5 & 5 & \\
\hline \multirow[t]{3}{*}{ DM03 } & sc01 & 1 & 3 & 4 & 2 & \\
\hline & \multicolumn{6}{|c|}{ Preference of Other Criteria over the Worst Criterion } \\
\hline & Worst Criterion & sc01 & sc02 & sc03 & sc04 & \\
\hline DM01 & $\mathrm{sc} 03$ & 3 & 3 & 1 & 2 & \\
\hline DM02 & $\mathrm{sc} 04$ & 7 & 6 & 4 & 1 & \\
\hline DM03 & $\mathrm{sc} 03$ & 4 & 2 & 1 & 3 & threshold \\
\hline DM01 & & 0.0000 & 0.0000 & 0.0000 & 0.1667 & \\
\hline DM02 & $C R_{j}^{I}$ & 0.1000 & 0.6500 & 0.7500 & 0.0000 & 0.2681 \\
\hline DM03 & & 0.0000 & 0.1667 & 0.0000 & 0.1667 & \\
\hline
\end{tabular}


Table 7. Best-to-others and others-to-worst vectors for subcriteria sc05 to sc09.

\begin{tabular}{|c|c|c|c|c|c|c|c|}
\hline \multirow[t]{2}{*}{ Decision-Maker } & \multicolumn{7}{|c|}{ Preference of the Best criterion over Others } \\
\hline & $\begin{array}{c}\text { Best } \\
\text { Criterion }\end{array}$ & $\mathrm{sc} 05$ & sc06 & $\mathrm{sc} 07$ & $\mathrm{sc} 08$ & $\mathrm{sc} 09$ & \\
\hline DM01 & sc05 & 1 & 6 & 4 & 2 & 3 & \\
\hline DM02 & sc05 & 1 & 5 & 4 & 4 & 5 & \\
\hline \multirow[t]{3}{*}{ DM03 } & sc05 & 1 & 4 & 3 & 2 & 3 & \\
\hline & \multicolumn{7}{|c|}{ Preference of Other Criteria over the Worst Criterion } \\
\hline & $\begin{array}{c}\text { Worst } \\
\text { Criterion }\end{array}$ & sc05 & $\mathrm{sc06}$ & sc07 & $\mathrm{sc} 08$ & sc09 & \\
\hline DM01 & sc06 & 7 & 1 & 4 & 6 & 3 & \\
\hline DM02 & sc06 & 8 & 1 & 7 & 7 & 5 & \\
\hline DM03 & $\mathrm{sc06}$ & 4 & 1 & 2 & 3 & 2 & threshold \\
\hline DM01 & & 0.0333 & 0.0000 & 0.3333 & 0.2000 & 0.1000 & \\
\hline DM02 & $C R_{j}^{I}$ & 0.1500 & 0.0000 & 1.1500 & 1.1500 & 1.0000 & 0.3062 \\
\hline DM03 & & 0.0000 & 0.0000 & 0.1667 & 0.1667 & 0.1667 & \\
\hline
\end{tabular}

Table 8. Revised best-to-others and others-to-worst vectors for main criteria.

\begin{tabular}{|c|c|c|c|c|c|c|c|c|}
\hline \multirow[t]{2}{*}{ Decision-Maker } & \multicolumn{8}{|c|}{ Preference of the Best Criterion over Others } \\
\hline & $\begin{array}{c}\text { Best } \\
\text { Criterion }\end{array}$ & MC1 & MC2 & MC3 & $\mathrm{MC} 4$ & MC5 & MC6 & \\
\hline DM01 & MC2 & 2 & 1 & 7 & 3 & 4 & 8 & \\
\hline DM02 & MC2 & 2 & 1 & 6 & 6 & 7 & 9 & \\
\hline \multirow[t]{3}{*}{ DM03 } & $\mathrm{MC2}$ & 2 & 1 & 5 & 4 & 3 & 5 & \\
\hline & \multicolumn{8}{|c|}{ Preference of Other Criteria over the Worst Criterion } \\
\hline & $\begin{array}{l}\text { Worst } \\
\text { Criterion }\end{array}$ & MC1 & MC2 & MC3 & MC4 & MC5 & MC6 & \\
\hline DM01 & MC6 & 9 & 9 & 3 & 6 & 6 & 1 & \\
\hline DM02 & MC6 & 9 & 9 & 4 & 5 & 4 & 1 & \\
\hline DM03 & MC6 & 4 & 5 & 2 & 2 & 3 & 1 & threshold \\
\hline DM01 & & 0.1786 & 0.0179 & 0.2321 & 0.1786 & 0.2857 & 0.0000 & \\
\hline DM02 & $C R_{j}^{I}$ & 0.1250 & 0.0000 & 0.2083 & 0.2917 & 0.2639 & 0.0000 & 0.3337 \\
\hline DM03 & & 0.1500 & 0.0000 & 0.2500 & 0.1500 & 0.2000 & 0.0000 & \\
\hline
\end{tabular}

Table 9. Revised best-to-others and others-to-worst vectors for subcriteria sc01 to sc04.

\begin{tabular}{|c|c|c|c|c|c|c|}
\hline \multirow[t]{2}{*}{ Decision-Maker } & \multicolumn{6}{|c|}{ Preference of the Best Criterion over Others } \\
\hline & Best Criterion & sc01 & $\mathrm{sc02}$ & $\mathrm{sc} 03$ & sc04 & \\
\hline DM01 & $\mathrm{sc} 02$ & 1 & 1 & 3 & 2 & \\
\hline DM02 & $\mathrm{sc} 01$ & 1 & 3 & 5 & 5 & \\
\hline \multirow[t]{3}{*}{ DM03 } & $\mathrm{sc} 01$ & 1 & 3 & 4 & 2 & \\
\hline & \multicolumn{6}{|c|}{ Preference of Other Criteria over the Worst Criterion } \\
\hline & Worst Criterion & sc01 & sc02 & sc03 & sc04 & \\
\hline DM01 & sc03 & 3 & 3 & 1 & 2 & \\
\hline DM02 & $\mathrm{sc} 04$ & 7 & 3 & 2 & 1 & \\
\hline DM03 & $\mathrm{sc} 03$ & 4 & 2 & 1 & 3 & threshold \\
\hline DM01 & & 0.0000 & 0.0000 & 0.0000 & 0.1667 & \\
\hline DM02 & $C R_{j}^{I}$ & 0.1000 & 0.2000 & 0.2500 & 0.0000 & 0.2681 \\
\hline DM03 & & 0.0000 & 0.1667 & 0.0000 & 0.1667 & \\
\hline
\end{tabular}


Table 10. Revised best-to-others and others-to-worst vectors for subcriteria sc05 to sc09.

\begin{tabular}{|c|c|c|c|c|c|c|c|}
\hline \multirow[t]{2}{*}{ Decision-Maker } & \multicolumn{7}{|c|}{ Preference of the Best criterion over Others } \\
\hline & $\begin{array}{c}\text { Best } \\
\text { Criterion }\end{array}$ & sc05 & sc06 & sc07 & sc08 & sc09 & \\
\hline DM01 & sc05 & 1 & 6 & 4 & 2 & 3 & \\
\hline DM02 & sc05 & 1 & 5 & 4 & 4 & 5 & \\
\hline \multirow[t]{3}{*}{ DM03 } & sc05 & 1 & 4 & 3 & 2 & 3 & \\
\hline & \multicolumn{7}{|c|}{ Preference of Other Criteria over the Worst Criterion } \\
\hline & $\begin{array}{l}\text { Worst } \\
\text { Criterion }\end{array}$ & sc05 & sc06 & sc07 & $\mathrm{sc} 08$ & sc09 & \\
\hline DM01 & sc06 & 7 & 1 & 3 & 6 & 3 & \\
\hline DM02 & sc06 & 8 & 1 & 2 & 2 & 2 & \\
\hline DM03 & sc06 & 4 & 1 & 2 & 3 & 2 & threshold \\
\hline DM01 & & 0.0333 & 0.0000 & 0.2000 & 0.2000 & 0.1000 & \\
\hline DM02 & $C R_{j}^{I}$ & 0.1500 & 0.0000 & 0.1500 & 0.1500 & 0.2500 & 0.3062 \\
\hline DM03 & & 0.0000 & 0.0000 & 0.1667 & 0.1667 & 0.1667 & \\
\hline
\end{tabular}

We used the linear model of BWM to obtain the optimized weights of criteria. For this purpose, "solver" add-in in Excel program was used as was available in the website https:/ / bestworsmethod.com/2020, (accessed on 15 August 2020). An example of using Excel Solver for main criteria is given in Figure 4.

After obtaining the optimal weights of criteria for each decision-maker, the integrated group weights are calculated. For this purpose, a weight was assigned and agreed on for each decision-maker to represent his/her degree of importance or influence in the group and the weighted average of individual criteria weights are considered as integrated group weights or group average. (Tables 11-13).

Table 11. Group weights for the main criteria.

\begin{tabular}{cccccccc}
\hline Decision-Maker & Weight of DM & MC1 & MC2 & MC3 & MC4 & MC5 & MC6 \\
\hline DM01 & 0.3333 & 0.2380 & 0.3807 & 0.0680 & 0.1586 & 0.1190 & 0.0357 \\
DM02 & 0.5000 & 0.2685 & 0.4381 & 0.0895 & 0.0895 & 0.0767 & 0.0377 \\
DM03 & 0.1667 & 0.2161 & 0.3798 & 0.0864 & 0.1081 & 0.1441 & 0.0655 \\
Group average & 0.2496 & 0.4093 & 0.0818 & 0.1156 & 0.1020 & 0.0417 \\
\hline
\end{tabular}

Table 12. Group weights for the subcriteria sc01 to sc04.

\begin{tabular}{cccccc}
\hline Decision-Maker & Weight of DM & sc01 & sc02 & sc03 & sc04 \\
\hline DM01 & 0.3333 & 0.3514 & 0.3514 & 0.1081 & 0.1892 \\
DM02 & 0.5000 & 0.5590 & 0.2174 & 0.1304 & 0.0932 \\
DM03 & 0.1667 & 0.4655 & 0.1724 & 0.1034 & 0.2586 \\
Group average & & 0.4742 & 0.2545 & 0.1185 & 0.1528 \\
\hline
\end{tabular}

Table 13. Group weights for the subcriteria sc05 to sc09.

\begin{tabular}{|c|c|c|c|c|c|c|}
\hline Decision-Maker & Weight of DM & sc05 & sc06 & sc07 & sc08 & sc09 \\
\hline DM01 & 0.3333 & 0.4110 & 0.0548 & 0.1233 & 0.2466 & 0.1644 \\
\hline DM02 & 0.5000 & 0.4962 & 0.0763 & 0.1527 & 0.1527 & 0.1221 \\
\hline DM03 & 0.1667 & 0.3971 & 0.0882 & 0.1471 & 0.2206 & 0.1471 \\
\hline \multicolumn{2}{|c|}{ Group average } & 0.4513 & 0.0711 & 0.1419 & 0.1953 & 0.1404 \\
\hline
\end{tabular}




\begin{tabular}{|c|c|c|c|c|c|c|}
\hline Criteria Number $=6$ & Criterion 1 & Criterion 2 & Criterion 3 & Criterion 4 & Criterion 5 & Criterion 6 \\
\hline Names of Criteria & MC1 & MC2 & MC3 & MC4 & MC5 & MC6 \\
\hline Select the Best & MC2 & & & & & \\
\hline Select the Worst & MC6 & & & & & \\
\hline Best to Others & MC1 & MC2 & MC3 & MC4 & MC5 & MC6 \\
\hline $\mathrm{MC2}$ & 2 & 1 & 7 & 3 & 4 & 8 \\
\hline Others to the Worst & MC6 & & & & & \\
\hline $\mathrm{MC1}$ & 9 & & & & & \\
\hline MC2 & 9 & & & & & \\
\hline MC3 & 3 & & & & & \\
\hline MC4 & 6 & & & & & \\
\hline MC5 & 6 & & & & & \\
\hline MC6 & 1 & & & & & \\
\hline \multirow{2}{*}{ Weights } & MC1 & MC2 & MC3 & MC4 & MC5 & MC6 \\
\hline & 0.23796034 & 0.38073654 & 0.06798867 & 0.15864023 & 0.11898017 & 0.03569405 \\
\hline Ksi* & 0.09518414 & & & & & \\
\hline
\end{tabular}

Weights

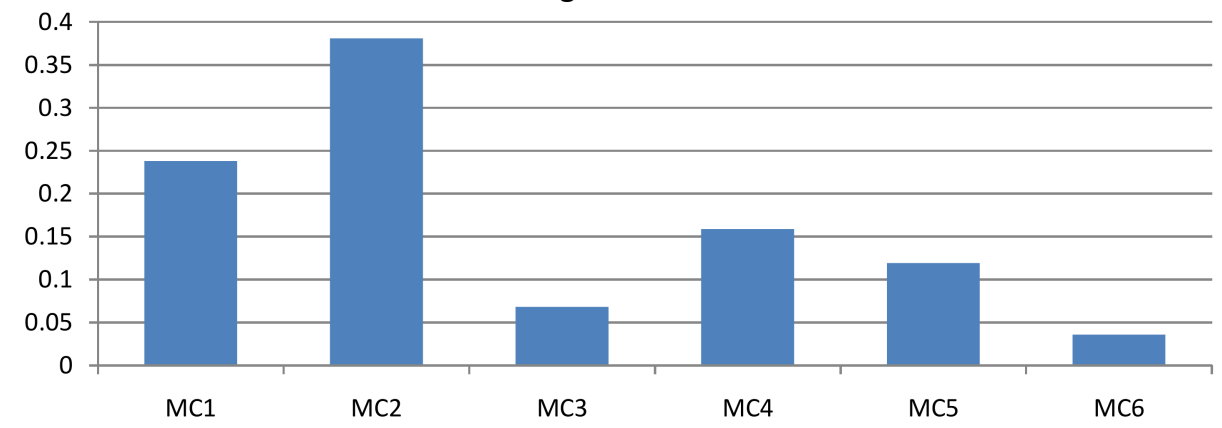

Figure 4. Solving linear BWM model by Excel Solver to obtain the main criteria weights for decisionmaker $01 .{ }^{*}$ The Ksi shows to what extent the results are reliable, the closer the Ksi to zero the better.

Multiplying the local weight of each subcriterion in the weight of related main criterion, the global weights of subcriteria are obtained (Table 14).

Table 14. Local and global weights and ranking of the subcriteria.

\begin{tabular}{|c|c|c|c|c|c|}
\hline Main Criteria & Main Criteria Weights & Subcriteria & Local Weights & Global Weights & Rank \\
\hline \multirow[t]{4}{*}{ MC1 } & 0.2496 & sc01 & 0.4742 & 0.1184 & 2 \\
\hline & & $\mathrm{sc} 02$ & 0.2545 & 0.0635 & 7 \\
\hline & & $\mathrm{sc} 03$ & 0.1185 & 0.0296 & 12 \\
\hline & & $\mathrm{sc} 04$ & 0.1528 & 0.0381 & 11 \\
\hline \multirow[t]{5}{*}{ MC2 } & 0.4093 & sc05 & 0.4513 & 0.1847 & 1 \\
\hline & & sc06 & 0.0711 & 0.0291 & 13 \\
\hline & & $\mathrm{sc} 07$ & 0.1419 & 0.0581 & 8 \\
\hline & & sc08 & 0.1953 & 0.0799 & 6 \\
\hline & & sc09 & 0.1404 & 0.0574 & 9 \\
\hline MC3 & 0.0818 & sc10 & 1.0000 & 0.0818 & 5 \\
\hline MC4 & 0.1156 & sc11 & 1.0000 & 0.1156 & 3 \\
\hline MC5 & 0.1020 & sc12 & 1.0000 & 0.1020 & 4 \\
\hline MC6 & 0.0417 & sc13 & 1.0000 & 0.0417 & 10 \\
\hline
\end{tabular}




\subsection{Decision Matrix}

Each element of a decision matrix denotes the performance value or score of each alternative with respect to each subcriterion. In the illustrative example, crisp values and some qualitative assessments of alternatives, were extracted directly from tender documents (subcriteria sc $01, \mathrm{sc} 02$, sc 03 , sc $05, \mathrm{sc} 07, \mathrm{sc} 08, \mathrm{sc} 09$, sc11, sc12, sc13). Qualitative sub-criteria sc 04, sc 06 and sc 10 were evaluated by decision-makers by linguistic variables (Table 15) and their equivalent fuzzy numbers determined. In Table 15 linguistic variables utilized in the illustrative example and their equivalent TFNs are shown. Arithmetic averages of the fuzzy values for all decision-makers were considered as performance values of the latter subcriteria. The decision matrix is established by integrating the above performance values with subcriteria weights in Table 16.

Table 15. Linguistic variables and their equivalent TFNs.

\begin{tabular}{ccc}
\hline Linguistic Variable & Abbreviation & TFN \\
\hline Very Good & VG & $(0.9,1,1)$ \\
Good & G & $(0.7,0.9,1)$ \\
Medium Good & MG & $(0.5,0.7,0.9)$ \\
Fair & F & $(0.3,0.5,0.7)$ \\
Medium Poor & MP & $(0.1,0.3,0.5)$ \\
Poor & P & $(0,0.1,0.3)$ \\
Very Poor & VP & $(0,0,0.1)$ \\
\hline
\end{tabular}

Table 16. Decision matrix for illustrative example.

\begin{tabular}{|c|c|c|c|c|c|c|c|c|c|c|c|c|c|}
\hline Criteria & sc01(+) & $\mathrm{sc02(+)}$ & sc03(+) & sc04(+) & sc05(+) & sc06(+) & sc07(+) & sc08(+) & $\operatorname{sc09(+)}$ & sc10(+) & sc11(-) & sc12(+) & $\operatorname{sc13}(+)$ \\
\hline Alternatives & $\begin{array}{l}\stackrel{+}{\infty} \\
\stackrel{\Xi}{二}\end{array}$ & 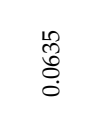 & $\begin{array}{l}\text { ठัे } \\
\text { ठे }\end{array}$ & $\begin{array}{l}\vec{\infty} \\
\stackrel{0}{0} \\
0\end{array}$ & $\begin{array}{l}\text { f } \\
\text { on } \\
\text { - }\end{array}$ & $\begin{array}{l}\text { ठิ } \\
\text { ठे. }\end{array}$ & $\begin{array}{l}\vec{\infty} \\
\ddot{0} \\
\ddot{0}\end{array}$ & $\begin{array}{l}\text { बे } \\
\text { Oे }\end{array}$ & $\begin{array}{l}\stackrel{+}{\Delta} \\
\text { to } \\
0\end{array}$ & $\begin{array}{l}\infty \\
\stackrel{\infty}{\infty} \\
0 \\
0\end{array}$ & $\begin{array}{l}\stackrel{\circ}{\circ} \\
\stackrel{7}{0}\end{array}$ & $\begin{array}{l}\text { तิ } \\
\text { Oे } \\
\stackrel{0}{0}\end{array}$ & $\begin{array}{l}\stackrel{A}{O} \\
\stackrel{+}{0} \\
\stackrel{0}{0}\end{array}$ \\
\hline A & 8 & 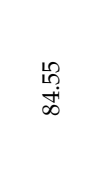 & तิ & 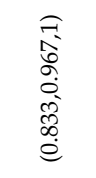 & $R$ & $\begin{array}{l}\hat{\kappa} \\
\delta \\
0 \\
\hat{0} \\
\infty \\
\infty \\
0 \\
\hat{0} \\
0\end{array}$ & $\begin{array}{l}\hat{a} \\
\vdots \\
\hat{0}\end{array}$ & $\begin{array}{l}\widehat{A} \\
0 \\
\hat{0} \\
\hat{e}\end{array}$ & $\begin{array}{l}\hat{\sigma} \\
0 \\
\hat{0} \\
0 \\
10 \\
0\end{array}$ & $\begin{array}{l}\text { न्. } \\
\text { बे } \\
\stackrel{0}{0}\end{array}$ & 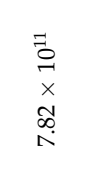 & $\stackrel{8}{\circ}$ & 0 \\
\hline B & 8 & 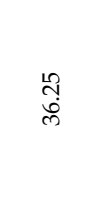 & $\stackrel{2}{N}$ & 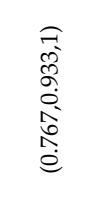 & in & $\begin{array}{l}\hat{F} \\
\vec{a} \\
\stackrel{e}{e}\end{array}$ & $\begin{array}{l}\sigma \\
0 \\
\hat{0} \\
0 \\
\vdots \\
0 \\
0\end{array}$ & $\begin{array}{l}\widehat{a} \\
0 \\
\hat{\vdots} \\
0 \\
0 \\
0\end{array}$ & $\begin{array}{l}\hat{E} \\
0 \\
10 \\
0 \\
0 \\
0 \\
0\end{array}$ & 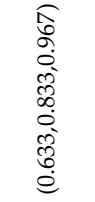 & $\begin{array}{l}\underset{7}{0} \\
\stackrel{1}{x} \\
\times \\
\infty \\
\stackrel{-}{+}\end{array}$ & $N$ & 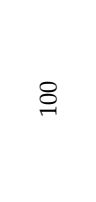 \\
\hline C & 8 & $\stackrel{\text { ?f }}{\stackrel{2}{R}}$ & 우 & 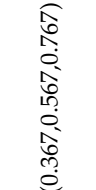 & 8 & $\begin{array}{l}\text { त̂ } \\
0 \\
0 \\
0 \\
0 \\
0 \\
\infty \\
0 \\
0 \\
0\end{array}$ & 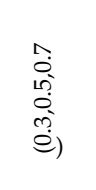 & $\begin{array}{l}\hat{a} \\
0 \\
\hat{0} \\
0 \\
\vdots \\
0\end{array}$ & $\begin{array}{l}\sigma \\
0 \\
\hat{0} \\
0 \\
i \\
0 \\
0\end{array}$ & 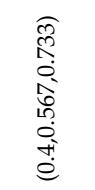 & 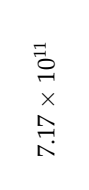 & 요 & $\stackrel{-}{\circ}$ \\
\hline D & $\stackrel{\infty}{\circ}$ & $\begin{array}{l}\stackrel{L}{2} \\
\infty \\
\infty\end{array}$ & 요 & 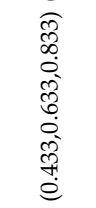 & 8 & 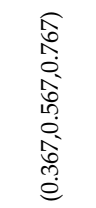 & $\begin{array}{l}\hat{\sigma} \\
0 \\
\hat{0} \\
0 \\
10 \\
0\end{array}$ & $\begin{array}{l}\widehat{E} \\
0 \\
10 \\
0 \\
0 \\
0 \\
e\end{array}$ & $\begin{array}{l}\hat{a} \\
\vdots \\
\hat{0} \\
\vdots \\
\stackrel{0}{0}\end{array}$ & 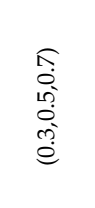 & 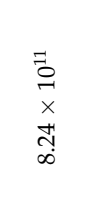 & $\underset{ }{\stackrel{9}{-1}}$ & 0 \\
\hline
\end{tabular}

In the Table 16, sign (+) denotes the benefit (positive) criteria and adversely, sing (-) denotes the cost (negative) criteria. 


\subsection{Ranking the Alternatives}

For ranking of alternatives (contractors), the fuzzy VIKOR algorithm is followed (Appendix A, Table A1). For homogenizing the fuzzy arithmetic operations, the crisp values of alternative's performances in the table were also shown as fuzzy triangular numbers, but the weights of criteria were dealt as crisp scalars.

Using the results of calculations in Table 17 , fuzzy values of $\widetilde{S}, \widetilde{R}, \widetilde{Q}$ could be calculated according to relations (19), (20) and (21). (Table 17)

To compare the fuzzy values of Table 17, they should be transformed to equivalent crisp values or defuzzified. For this purpose, we utilized the second weighted mean method according to relation (9). In the Table 18, the results of defuzzification of fuzzy values and ranking of alternatives with respect to them, are shown.

Table 17. Calculations of fuzzy parameters: $\widetilde{S}_{i}, \widetilde{R}_{i}$ and $\widetilde{Q}_{i}$.

\begin{tabular}{cccc}
\hline & $\tilde{S}_{i}$ & $\tilde{\boldsymbol{R}}_{\boldsymbol{i}}$ & $\tilde{Q}_{i}$ \\
\hline A & $(-0.05,0.078,0.205)$ & $(0.042,0.042,0.042)$ & $(-0.186,0,0.186)$ \\
B & $(0.335,0.496,0.633)$ & $(0.185,0.185,0.185)$ & $(0.595,0.806,1)$ \\
C & $(0.215,0.395,0.533)$ & $(0.102,0.102,0.102)$ & $(0.219,0.443,0.638)$ \\
D & $(0.233,0.419,0.562)$ & $(0.118,0.118,0.118)$ & $(0.289,0.517,0.716)$ \\
$\widetilde{S}^{*}$ & $(-0.05,0.078,0.205)$ & & \\
$\widetilde{R}^{*}$ & & $(0.042,0.042,0.042)$ & \\
$S^{* l}$ & -0.050 & $R^{* l}$ & 0.042 \\
$S^{\text {ou }}$ & 0.633 & $R^{\circ u}$ & 0.185 \\
\hline
\end{tabular}

Table 18. Ranking of alternative with respect to the crisp values of $S, R$ and $Q$.

\begin{tabular}{ccccccc}
\hline \multirow{2}{*}{ Alternatives } & \multicolumn{3}{c}{ Parameters } & \multicolumn{3}{c}{ Rankings (with Respect to) } \\
\cline { 2 - 7 } & $\boldsymbol{S}_{\boldsymbol{i}}$ & $\boldsymbol{R}_{\boldsymbol{i}}$ & $\boldsymbol{Q}_{\boldsymbol{i}}$ & $\boldsymbol{S}_{\boldsymbol{i}}$ & $\boldsymbol{R}_{\boldsymbol{i}}$ & $\boldsymbol{Q}_{\boldsymbol{i}}$ \\
\hline $\mathrm{A}$ & 0.0778 & 0.0417 & 0.0000 & 1 & 1 & 1 \\
B & 0.4900 & 0.1847 & 0.8018 & 4 & 4 & 4 \\
C & 0.3846 & 0.1020 & 0.4357 & 2 & 2 & 2 \\
D & 0.4081 & 0.1184 & 0.5100 & 3 & 3 & 3 \\
\hline
\end{tabular}

In this step, two conditions should be examined to determine a preferable alternative:

Condition 1. Acceptable advantage:

$$
\begin{aligned}
& A d v \geq D Q \\
& D Q=1 /(m-1)=0.25(\text { since, } m \leq 4) \\
& A d v=\left[Q\left(A^{\prime \prime}\right)-Q\left(A^{\prime}\right)\right] /\left[Q\left(A^{(m)}\right)-Q\left(A^{\prime}\right)\right]=0.5434 \geq D Q(\text { O.K.) }
\end{aligned}
$$

Condition 2. Acceptable stability in decision making:

Alternative $A$ has also the first rank with respect to parameters $R$ and S. So, Condition 2 is also satisfied and this alternative is opted out as the preferable alternative. It should be reminded that in real tender, alternative $C$ had been chosen and awarded the project solely because of bidding the least price.

\subsection{Results and Discussion}

As mentioned in the previous subsection, in the real tender which was held by the rule of "the least bid price", alternative $C$ had been selected as the most competent contractor. The resultant compromise solution of the proposed model is, however, the alternative A. In other words, under the obligation of legal restrictions imposed by tender law in Iran, the selected alternative differs from the selected alternative of a group of experienced decision-makers of the client. 
A comparison between the two alternatives with respect to the 13 criteria shows that, except criteria sc11 (bid price) and sc13 (being native), contractor A is superior or at least in the same level as contractor $C$ with respect to all other criteria. As a matter of fact, they are in equal conditions in criteria sc01 (technical labor) and sc09 (commitment to schedule and time in past projects) and in all nine remaining criteria, contractor A has superiority over contractor $\mathrm{C}$. In terms of criteria weights, the total weights of those criteria in which contractor $A$ is at an upper or same position as contractor $C$, sum up to about 0.85 , while the sum of the weights of remaining two criteria is about 0.15 . In terms of money, the difference between bid prices of these contractors is about 65 billion Rials, which is about $9 \%$ of the least bid price. (Refer to Table 4).

Although there had been a prequalification phase in the tender which was used to filter a total of 20 contractors and obtain a short list of competent contractors, the prominent criterion in the final phase according to the tender law in Iran is the least bid price. On the other side, according to the results of this study, from the point of the view of a group of top experts in the client's organization, the weight of the "bid price" criterion should have been confined to only $12 \%$ of total weights of the criteria (refer to Table 14).

The criteria weights in this study were determined via a verified multicriteria decisionmaking method (i.e., BWM). For this aim, a survey was carried out among a group of senior managers of the client. For this reason, the selected criteria and particularly, their weights could guarantee the success of the project, insomuch as the project's success is related to CS. As a matter of fact, the client has obligatorily, and maybe unconsciously, given up the evident capabilities of alternative A in compromise with a seemingly monetary gain and by doing so, the success of the project has been jeopardized to some extent. This obligation has been imposed by the legal restrictions of the tender law in Iran.

Contemplating the assigned weights of the criteria reveals some facts about the project's characteristics and the point of view of the client's decision-makers. Referring to Table 14 shows that "similar past projects", "technical labor", "bid price", "financial strength" and "proposed schedule" are respectively the most important criteria from the point of view of the decision-makers. Total weight of these criteria sums up to about 0.60 . The first criterion in the rank is "similar past project". This shows the tendency of the client to cooperate with a contractor who has done similar projects in the past and is ready to apply the past experience in the present project. This experience helps the contractor to foresee the future difficulties and problems in advance and avoid reworkings which may cause delays and cost overruns in the project.

Lack of suitable technical labor is also a cause of time delays and quality shortcomings. The bid price is also important for the client but it is not so important as to sacrifice the other aspects of the project's success. So, its weight was limited to only about 12 percent.

"Financial strength" of the contractors is also among the most significant criteria, for the financial difficulties on the side of the client during the project, may lead to an inactivity period. Financial strength of contractors helps to cover these periods and prevents delays.

There is an obvious contradiction between the client's criteria and requirements for CS on one hand and the selected contractor in reality on the other hand, for the only superiority of the selected contractor over the best one, is the lower bid price ( $9 \%$ lower than the best one). This fact can be regarded as a proof for the importance of the proposed model in assessment and selection of a contractor for a construction project.

However, according to the tender law in Iran, selection of a contractor for a construction project is executed by considering the single criterion of the lower bid price after a prequalification phase. The clients of the public sector have legal commitments to follow these rules. In spite of the apparent flaws of this method, it is not fair to relate all of the projects' shortcomings or even failures to the contractors' deficiencies, for in many cases the causes of delay or failure are the shortages or incompetency on the client side such as financial problems and so on. For this reason, the difficulties on the contractors' side do not often come to the surface. 


\section{Conclusions}

In this paper, a new model based on MCDM methods was proposed to address the CS problem for construction projects as a solution to evade the traditional method of awarding construction projects, particularly in Iran. The well-known and relatively new BWM method was utilized as a tool for weighting the criteria for its simplicity and consistency of results. In addition, the fuzzy-VIKOR method was applied as a tool for ranking the alternatives for its effectiveness in dealing with conflicting criteria and in the condition of incomplete or vague information about the contractors' performance.

Integration of two methods in the proposed model provides a systematic method for assessment and selection of a contractor for a construction project. The integrated model has the potential of entering into the processes of tenders in Iran, provided that the legal restrictions would be removed.

In the proposed model, there is the possibility of considering any criterion that is crucial for the success of the project and should be taken into account in the process of CS. These criteria may be quantitative, qualitative, and even may have fuzzy characteristics to consider uncertainty of conditions or incompleteness in the data. The criteria may have different dimensions and may be of benefit (positive) or cost (negative) nature. Therefore, it provides a flexible ground for the client to choose all criteria that match the project's requirements and satisfy the client's demands.

Finally, the illustrative example showed the applicability of the proposed model in practice. The apparent advantages of the selected alternative of the model over the winner of the real tender, was a proof of the validity of the proposed model.

There were some limitations regarding the implementation of the proposed model in an ongoing tender process due to the legal restrictions in the public sector of Iran. It is recommended for the future researchers to apply the proposed model in an ongoing real tender in public or private sectors as a case study.

In addition, the ranking of the alternatives with other MCDM methods and comparing the results can be another topic for further research. Moreover, there exists the possibility of using the nonlinear BWM model as well as the fuzzy BWM method for obtaining the optimized weights of the criteria. Furthermore, the proposed model has the capacity to be applied to any set of criteria associated with the stakeholders' and project's requirements. Hence, the proposed model can be implemented in various projects with different characteristics.

Author Contributions: Conceptualization, A.N.V. and R.A.; methodology, A.N.V. and M.K.; software, A.N.V.; validation, M.K. and R.A.; formal analysis, A.N.V.; investigation, A.N.V.; resources, A.N.V., M.K. and R.A.; data curation, A.N.V.; writing—original draft preparation, A.N.V.; writing-review and editing, M.K., J.A. and R.B.; funding acquisition, J.A. and R.B. All authors have read and agreed to the published version of the manuscript.

Funding: This research received no external funding.

Institutional Review Board Statement: Not applicable.

Informed Consent Statement: Not applicable.

Data Availability Statement: Data sharing not applicable.

Acknowledgments: We greatly appreciate Ayyub Minaei and his colleagues for their help in acquiring necessary data for the illustrative example. The Author \#1 thanks his wife Maryam Najjari for her support and encouragement during the research. We also are very thankful to the editorial and production teams in MDPI for their help and valuable efforts in the publication of the paper.

Conflicts of Interest: The authors declare no conflict of interest. 


\section{Appendix A}

Table A1. Fuzzy-VIKOR calculations.

\begin{tabular}{|c|c|c|c|c|c|c|c|c|c|c|c|c|c|c|}
\hline & iteria & sc01 & sc02 & sc03 & sc04 & sc05 & sc06 & sc07 & sc08 & sc09 & sc10 & sc11 & sc12 & sc13 \\
\hline & $\begin{array}{l}\text { iteria } \\
\text { ights }\end{array}$ & 0.1184 & 0.0635 & 0.0296 & 0.0381 & 0.1847 & 0.0291 & 0.0581 & 0.0799 & 0.0574 & 0.0818 & 0.1156 & 0.1020 & 0.0417 \\
\hline \multirow{6}{*}{ 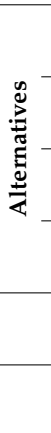 } & A & $(60,60,60)$ & $\begin{array}{c}(84.55,84.55, \\
84.55)\end{array}$ & $(20,20,20)$ & $(0.833,0.967,1)$ & $(70,70,70)$ & $(0.7,0.867,0.967)$ & $(0.7,0.9,1)$ & $(0.7,0.9,1)$ & $(0.5,0.7,0.9)$ & $(0.9,1,1)$ & $\begin{array}{c}(782000000000,782000000000, \\
782000,000,000)\end{array}$ & $(100,100,100)$ & $(0,0,0)$ \\
\hline & B & $(60,60,60)$ & $\begin{array}{l}(36.25,36.25, \\
36.25)\end{array}$ & $(25,25,25)$ & $(0.767,0.933,1)$ & $(50,50,50)$ & $(0.9,1,1)$ & $(0.5,0.7,0.9)$ & $(0.5,0.7,0.9)$ & $(0.3,0.5,0.7)$ & $(0.633,0.833,0.967)$ & $\begin{array}{c}(1077195211299,1077195211299 \\
1077195211299)\end{array}$ & $(72,72,72)$ & $(100,100,100)$ \\
\hline & $\mathrm{C}$ & $(60,60,60)$ & $\begin{array}{l}(70.45,70.45 \\
70.45)\end{array}$ & $(10,10,10)$ & $\begin{array}{l}(0.367,0.567 \\
0.767)\end{array}$ & $(60,60,60)$ & $(0.333,0.5,0.667)$ & $(0.3,0.5,0.7)$ & $(0.5,0.7,0.9)$ & $(0.5,0.7,0.9)$ & $(0.4,0.567,0.733)$ & $\begin{array}{c}(717135210855,717135210855 \\
717135210855)\end{array}$ & $(45,45,45)$ & $(100,100,100)$ \\
\hline & D & $(48,48,48)$ & $\begin{array}{c}(78.05,78.05, \\
78.05)\end{array}$ & $(20,20,20)$ & $\begin{array}{c}(0.433,0.633 \\
0.833) \\
\end{array}$ & $(65,65,65)$ & $\begin{array}{l}(0.367,0.567 \\
0.767)\end{array}$ & $(0.5,0.7,0.9)$ & $(0.3,0.5,0.7)$ & $(0.5,0.7,0.9)$ & $(0.3,0.5,0.7)$ & $\begin{array}{c}(823639532214,823639532214 \\
823639532214)\end{array}$ & $(100,100,100)$ & $(0,0,0)$ \\
\hline & $f^{\sim+}$ & $(60,60,60)$ & $\begin{array}{l}(84.55,84.55, \\
84.55)\end{array}$ & $(25,25,25)$ & $(0.833,0.967,1)$ & $(70,70,70)$ & $(0.9,1,1)$ & $(0.7,0.9,1)$ & $(0.7,0.9,1)$ & $(0.5,0.7,0.9)$ & $(0.9,1,1)$ & $\begin{array}{c}(717135210855,717135210855 \\
717135210855)\end{array}$ & $(100,100,100)$ & $(100,100,100)$ \\
\hline & $\mathbf{f}^{\sim-}$ & $(48,48,48)$ & $\begin{array}{l}(36.25,36.25, \\
36.25)\end{array}$ & $(10,10,10)$ & $\begin{array}{c}(0.367,0.567 \\
0.767)\end{array}$ & $(50,50,50)$ & $\begin{array}{c}(0.333,0.5 \\
0.667) \\
\end{array}$ & $(0.3,0.5,0.7)$ & $(0.3,0.5,0.7)$ & $(0.3,0.5,0.7)$ & $(0.3,0.5,0.7)$ & $\begin{array}{c}(1077195211299,1077195211299 \\
1077195211299)\end{array}$ & $(45,45,45)$ & $(0,0,0)$ \\
\hline \multirow{3}{*}{ 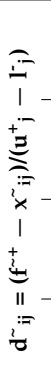 } & A & $(0,0,0)$ & $(0,0,0)$ & $\begin{array}{l}(0.333, \\
0.333, \\
0.333)\end{array}$ & $\begin{array}{l}(-0.264,0 \\
0.264)\end{array}$ & $(0,0,0)$ & $\begin{array}{l}(-0.1 \\
0.199 \\
0.45)\end{array}$ & $\begin{array}{l}(-0.429,0 \\
0.429)\end{array}$ & $\begin{array}{l}(-0.429,0 \\
0.429)\end{array}$ & $\begin{array}{l}(-0.667,0, \\
0.667)\end{array}$ & $\begin{array}{l}(-0.143,0 \\
0.143)\end{array}$ & $\begin{array}{l}(0.18, \\
0.18, \\
0.18)\end{array}$ & $(0,0,0)$ & $(1,1,1)$ \\
\hline & B & $(0,0,0)$ & $(1,1,1)$ & $(0,0,0)$ & $\begin{array}{c}(-0.264, \\
0.054, \\
0.368)\end{array}$ & $(1,1,1)$ & $\begin{array}{l}(-0.15,0, \\
0.15)\end{array}$ & $\begin{array}{c}(-0.286, \\
0.286, \\
0.714)\end{array}$ & $\begin{array}{c}(-0.286 \\
0.286 \\
0.714)\end{array}$ & $\begin{array}{l}(-0.333, \\
0.333,1)\end{array}$ & $\begin{array}{c}(-0.096, \\
0.239 \\
0.524)\end{array}$ & $(1,1,1)$ & $\begin{array}{l}(0.509 \\
0.509, \\
0.509)\end{array}$ & $(0,0,0)$ \\
\hline & D & $(1,1,1)$ & $\begin{array}{l}(0.135 \\
0.135, \\
0.135)\end{array}$ & $\begin{array}{l}(0.333, \\
0.333, \\
0.333)\end{array}$ & $\begin{array}{l}(0,0.528, \\
0.896)\end{array}$ & $\begin{array}{l}(0.25, \\
0.25, \\
0.25)\end{array}$ & $\begin{array}{c}(0.199 \\
0.649 \\
0.949)\end{array}$ & $\begin{array}{c}(-0.286 \\
0.286 \\
0.714)\end{array}$ & $(0,0.571,1)$ & $\begin{array}{l}(-0.667,0, \\
0.667)\end{array}$ & $\begin{array}{r}(0.286, \\
0.714,1)\end{array}$ & $\begin{array}{l}(0.296,0.296 \\
0.296)\end{array}$ & $(0,0,0)$ & $(1,1,1)$ \\
\hline \multirow{4}{*}{$\begin{array}{l}:= \\
\frac{i}{2} \\
\frac{1}{3}-\end{array}$} & A & $(0,0,0)$ & $(0,0,0)$ & $(0.01,0.01,0.01)$ & $(-0.01,0,0.01)$ & $(0,0,0)$ & $\begin{array}{l}(-0.003,0.006 \\
0.013)\end{array}$ & $\begin{array}{l}(-0.025,0 \\
0.025)\end{array}$ & $\begin{array}{l}(-0.034,0 \\
0.034)\end{array}$ & $\begin{array}{l}(-0.038,0, \\
0.038)\end{array}$ & $\begin{array}{l}(-0.012,0, \\
0.012)\end{array}$ & $\begin{array}{l}(0.021,0.021 \\
0.021)\end{array}$ & $(0,0,0)$ & $\begin{array}{c}(0.042,0.042, \\
0.042)\end{array}$ \\
\hline & B & $(0,0,0)$ & $\begin{array}{c}(0.064,0.064, \\
0.064)\end{array}$ & $(0,0,0)$ & $\begin{array}{c}(-0.01,0.002 \\
0.014)\end{array}$ & $\begin{array}{l}(0.185,0.185, \\
0.185)\end{array}$ & $\begin{array}{l}(-0.004,0 \\
0.004)\end{array}$ & $\begin{array}{l}(-0.017,0.017 \\
0.041)\end{array}$ & $\begin{array}{c}(-0.023,0.023, \\
0.057)\end{array}$ & $\begin{array}{l}(-0.019,0.019 \\
0.057)\end{array}$ & $\begin{array}{c}(-0.008,0.02, \\
0.043)\end{array}$ & $\begin{array}{l}(0.116,0.116 \\
0.116)\end{array}$ & $\begin{array}{l}(0.052,0.052, \\
0.052)\end{array}$ & $(0,0,0)$ \\
\hline & C & $(0,0,0)$ & $\begin{array}{l}(0.019,0.019, \\
0.019)\end{array}$ & $(0.03,0.03,0.03)$ & $\begin{array}{l}(0.004,0.024 \\
0.038)\end{array}$ & $\begin{array}{l}(0.092,0.092, \\
0.092)\end{array}$ & $\begin{array}{l}(0.01,0.022, \\
0.029)\end{array}$ & $\begin{array}{c}(0,0.033, \\
0.058)\end{array}$ & $\begin{array}{l}(-0.023,0.023 \\
0.057)\end{array}$ & $\begin{array}{l}(-0.038,0, \\
0.038)\end{array}$ & $\begin{array}{l}(0.02,0.051 \\
0.07)\end{array}$ & $(0,0,0)$ & $\begin{array}{l}(0.102,0.102 \\
0.102)\end{array}$ & $(0,0,0)$ \\
\hline & D & $\begin{array}{l}(0.118,0.118, \\
0.118)\end{array}$ & $\begin{array}{l}(0.009,0.009, \\
0.009)\end{array}$ & $\begin{array}{l}(0.01,0.01 \\
0.01)\end{array}$ & $\begin{array}{l}(0,0.02, \\
0.034)\end{array}$ & $\begin{array}{l}(0.046,0.046, \\
0.046)\end{array}$ & $\begin{array}{c}(0.006,0.019 \\
0.028)\end{array}$ & $\begin{array}{l}(-0.017,0.017 \\
0.041)\end{array}$ & $(0,0.046,0.08)$ & $\begin{array}{l}(-0.038,0 \\
0.038)\end{array}$ & $\begin{array}{l}(0.023,0.058 \\
0.082)\end{array}$ & $\begin{array}{l}(0.034,0.034, \\
0.034)\end{array}$ & $(0,0,0)$ & $\begin{array}{c}(0.042,0.042, \\
0.042)\end{array}$ \\
\hline
\end{tabular}




\section{References}

1. El-Sayegh, S.M.; Basamji, M.; Haj Ahmad, A.; Zarif, N. Key contractor selection criteria for green construction projects in the UAE. Int. J. Construct. Manag. 2019, 1-11. [CrossRef]

2. Alptekin, O.; Alptekin, N. Analysis of Criteria Influencing Contractor Selection Using TOPSIS Method; IOP Publishing: Bristol, UK, 2017; p. 062003.

3. Banaitiene, N.; Banaitis, A. Analysis of criteria for contractors' qualification evaluation. Technol. Econ. Dev. Econ. 2006, 12, 276-282. [CrossRef]

4. Jafari, A. A contractor pre-qualification model based on the quality function deployment method. Constr. Manag. Econ. 2013, 31, 746-760. [CrossRef]

5. Hasnain, M.; Thaheem, M.J.; Ullah, F. Best Value Contractor Selection in Road Construction Projects: ANP-Based Decision Support System. Int. J. Civ. Eng. 2018, 16, 695-714. [CrossRef]

6. Kashiwagi, D.; Byfield, R. State of Utah performance information procurement system tests. J. Constr. Eng. Manag. 2002, 128, 338-347. [CrossRef]

7. El-Sayegh, S.M. Multi-criteria decision support model for selecting the appropriate construction management at risk firm. Constr. Manag. Econ. 2009, 27, 385-398. [CrossRef]

8. Morkunaite, Z.; Podvezko, V.; Zavadskas, E.K.; Bausys, R. Contractor selection for renovation of cultural heritage buildings by PROMETHEE method. Arch. Civ. Mech. Eng. 2019, 19, 1056-1071. [CrossRef]

9. Morkunaite, Z.; Bausys, R.; Zavadskas, E.K. Contractor Selection for Sgraffito Decoration of Cultural Heritage Buildings Using the WASPAS-SVNS Method. Sustainability 2019, 11, 6444. [CrossRef]

10. Rezaei, J. Best-worst multi-criteria decision-making method. Omega 2015, 53, 49-57. [CrossRef]

11. Opricovic, S.; Tzeng, G.-H. Compromise solution by MCDM methods: A comparative analysis of VIKOR and TOPSIS. Eur. J. Oper. Res. 2004, 156, 445-455. [CrossRef]

12. Opricovic, S. Fuzzy VIKOR with an application to water resources planning. Expert Syst. Appl. 2011, 38, 12983-12990. [CrossRef]

13. Fei, L.; Deng, Y.; Hu, Y. DS-VIKOR: A new multi-criteria decision-making method for supplier selection. Int. J. Fuzzy Syst. 2019, 21, 157-175. [CrossRef]

14. Darvish, M.; Yasaei, M.; Saeedi, A. Application of the graph theory and matrix methods to contractor ranking. Int. J. Proj. Manag. 2009, 27, 610-619. [CrossRef]

15. Fong, P.S.-W.; Choi, S.K.-Y. Final contractor selection using the analytical hierarchy process. Constr. Manag. Econ. 2000, 18, 547-557. [CrossRef]

16. Al-Harbi, K.M.A.-S. Application of the AHP in project management. Int. J. Proj. Manag. 2001, 19, 19-27. [CrossRef]

17. Topcu, Y.I. A decision model proposal for construction contractor selection in Turkey. Build. Environ. 2004, 39, 469-481. [CrossRef]

18. Hadidi, L.A.; Khater, M.A. Loss prevention in turnaround maintenance projects by selecting contractors based on safety criteria using the analytic hierarchy process (AHP). J. Loss Prev. Process Ind. 2015, 34, 115-126. [CrossRef]

19. Chiang, F.-Y.; Yu, V.F.; Luarn, P. Construction Contractor Selection in Taiwan Using AHP. Int. J. Eng. Technol. 2017, 9, 211-215. [CrossRef]

20. Abdelrahman, M.; Zayed, T.; Elyamany, A. Best-Value Model Based on Project Specific Characteristics. J. Constr. Eng. Manag. 2008, 134, 179-188. [CrossRef]

21. Nieto-Morote, A.; Ruz-Vila, F. A fuzzy multi-criteria decision-making model for construction contractor prequalification. Autom. Constr. 2012, 25, 8-19. [CrossRef]

22. San Cristóbal, J.R. Contractor selection using multicriteria decision-making methods. J. Constr. Eng. Manag. 2012, 138, 751-758. [CrossRef]

23. Polat, G. Subcontractor selection using the integration of the AHP and PROMETHEE methods. J. Civ. Eng. Manag. 2016, 22, 1042-1054. [CrossRef]

24. Taylan, O.; Kabli, M.R.; Porcel, C.; Herrera-Viedma, E. Contractor Selection for Construction Projects Using Consensus Tools and Big Data. Int. J. Fuzzy Syst. 2018, 20, 1267-1281. [CrossRef]

25. Cheng, E.W.L.; Li, H. Contractor selection using the analytic network process. Constr. Manag. Econ. 2004, 22, 1021-1032. [CrossRef]

26. Khosrowshahi, F. Neural network model for contractors' prequalification for local authority projects. Eng. Constr. Archit. Manag. 1999, 6, 315-328. [CrossRef]

27. Lam, K.C.; Ng, S.T.; Tiesong, H.; Skitmore, M.; Cheung, S.O. Decision support system for contractor pre-qualification-artificial neural network model. Eng. Constr. Archit. Manag. 2000, 7, 251-266.

28. Lam, K.C.; Hu, T.; Thomas Ng, S.; Skitmore, M.; Cheung, S.O. A fuzzy neural network approach for contractor prequalification. Constr. Manag. Econ. 2001, 19, 175-188. [CrossRef]

29. El-Sawalhi, N.; Eaton, D.; Rustom, R. Contractor pre-qualification model: State-of-the-art. Int. J. Proj. Manag. 2007, 25, 465-474. [CrossRef]

30. Hassim, S.; Muniandy, R.; Alias Aidi, H.; Abdullah, P. Construction tender price estimation standardization (TPES) in Malaysia: Modeling using fuzzy neural network. Eng. Constr. Archit. Manag. 2018, 25, 443-457. [CrossRef]

31. Moselhi, O.; Martinelli, A. Analysis of bids using multiattribute utility theory. In Proceedings of the International Symposium on Building Economics and Construction Management, Sydney, Australia, 9 June 1990; pp. 335-345.

32. Holt, G.D.; Olomolaiye, P.O.; Harris, F.C. Evaluating performance potential in the selection of construction contractors. Eng. Constr. Archit. Manag. 1994, 1, 29-50. [CrossRef]

33. Holt, G.D. Applying cluster analysis to construction contractor classification. Build. Environ. 1996, 31, 557-568. [CrossRef] 
34. Hatush, Z.; Skitmore, M. Criteria for contractor selection. Constr. Manag. Econ. 1997, 15, 19-38. [CrossRef]

35. Hatush, Z.; Skitmore, M. Contractor selection using multicriteria utility theory: An additive model. Build. Environ. 1998, 33, 105-115. [CrossRef]

36. Ng, S.T. EQUAL: A case-based contractor prequalifier. Autom. Constr. 2001, 10, 443-457. [CrossRef]

37. Sönmez, M.; Holt, G.D.; Yang, J.B.; Graham, G. Applying evidential reasoning to prequalifying construction contractors. J. Manag. Eng. 2002, 18, 111-119. [CrossRef]

38. Wong, C.H.; Nicholas, J.; Holt, G.D. Using multivariate techniques for developing contractor classification models. Eng. Constr. Archit. Manag. 2003, 10, 99-116. [CrossRef]

39. Lai, K.K.; Liu, S.L.; Wang, S.Y. A method used for evaluating bids in the Chinese construction industry. Int. J. Proj. Manag. 2004, 22, 193-201. [CrossRef]

40. Wong, C.H. Contractor performance prediction model for the United Kingdom construction contractor: Study of logistic regression approach. J. Constr. Eng. Manag. 2004, 130, 691-698. [CrossRef]

41. Minchin, R.E., Jr.; Smith, G.R. Quality-based contractor rating model for qualification and bidding purposes. J. Manag. Eng. 2005, 21, 38-43. [CrossRef]

42. McCabe, B.; Tran, V.; Ramani, J. Construction prequalification using data envelopment analysis. Can. J. Civ. Eng. 2005, 32, 183-193. [CrossRef]

43. Palaneeswaran, E.; Kumaraswamy, M.M. Web-based client advisory decision support system for design-builder prequalification. J. Comput. Civ. Eng. 2005, 19, 69-82. [CrossRef]

44. Kaklauskas, A.; Zavadskas, E.K.; Raslanas, S.; Ginevicius, R.; Komka, A.; Malinauskas, P. Selection of low-e windows in retrofit of public buildings by applying multiple criteria method COPRAS: A Lithuanian case. Energy Build. 2006, 38, 454-462. [CrossRef]

45. Lambropoulos, $\mathrm{S}$. The use of time and cost utility for construction contract award under European Union Legislation. Build. Environ. 2007, 42, 452-463. [CrossRef]

46. Brauers, W.K.M.; Zavadskas, E.K.; Turskis, Z.; Vilutienè, T. Multi-objective contractor's ranking by applying the Moora method. J. Bus. Econ. Manag. 2008, 9, 245-255. [CrossRef]

47. Zavadskas, E.K.; Turskis, Z.; Tamošaitiene, J. Contractor selection of construction in a competitive environment. J. Bus. Econ. Manag. 2008, 9, 181-187. [CrossRef]

48. Lam, K.C.; Palaneeswaran, E.; Yu, C.-y. A support vector machine model for contractor prequalification. Autom. Constr. 2009, 18, 321-329. [CrossRef]

49. Lam, K.-C.; Lam, M.C.-K.; Wang, D. Efficacy of using support vector machine in a contractor prequalification decision model. J. Comput. Civ. Eng. 2010, 24, 273-280. [CrossRef]

50. de Araújo, M.C.B.; Alencar, L.H.; Mota, C.M.M. Model for contractor performance evaluation in construction industry. In Proceedings of the 2016 IEEE International Conference on Systems, Man, and Cybernetics (SMC), Budapest, Hungary, 9-12 October 2016; pp. 002631-002635.

51. Keshavarz-Ghorabaee, M.; Amiri, M.; Zavadskas, E.K.; Turskis, Z.; Antucheviciene, J. A dynamic fuzzy approach based on the EDAS method for multi-criteria subcontractor evaluation. Information 2018, 9, 68. [CrossRef]

52. Russell, J.S.; Skibniewski, M.J. QUALIFIER-1: Contractor prequalification model. J. Comput. Civ. Eng. 1990, 4, 77-90. [CrossRef]

53. Hatush, Z.; Skitmore, M. Assessment and evaluation of contractor data against client goals using PERT approach. Constr. Manag. Econ. 1997, 15, 327-340. [CrossRef]

54. Mahdi, I.M.; Riley, M.J.; Fereig, S.M.; Alex, A.P. A multi-criteria approach to contractor selection. Eng. Constr. Archit. Manag. 2002, 9, 29-37.

55. Singh, D.; Tiong, R.L.K. A fuzzy decision framework for contractor selection. J. Constr. Eng. Manag. 2005, 131, 62-70. [CrossRef]

56. Turskis, Z. Multi-attribute contractors ranking method by applying ordering of feasible alternatives of solutions in terms of preferability technique. Technol. Econ. Dev. Econ. 2008, 14, 224-239. [CrossRef]

57. Plebankiewicz, E. Contractor prequalification model using fuzzy sets. J. Civ. Eng. Manag. 2009, 15, 377-385. [CrossRef]

58. Juan, Y.-K.; Perng, Y.-H.; Castro-Lacouture, D.; Lu, K.-S. Housing refurbishment contractors selection based on a hybrid fuzzy-QFD approach. Autom. Constr. 2009, 18, 139-144. [CrossRef]

59. Cheng, M.-Y.; Kang, S.-T. Integrated fuzzy preference relations with decision utilities for construction contractor selection. J. Chin. Inst. Eng. 2012, 35, 1051-1063. [CrossRef]

60. Plebankiewicz, E. A fuzzy sets-based contractor prequalification procedure. Autom. Constr. 2012, 22, 433-443. [CrossRef]

61. Vahdani, B.; Mousavi, S.M.; Hashemi, H.; Mousakhani, M.; Tavakkoli-Moghaddam, R. A new compromise solution method for fuzzy group decision-making problems with an application to the contractor selection. Eng. Appl. Artif. Intell. 2013, 26, 779-788. [CrossRef]

62. Attar, A.M.; Khanzadi, M.; Dabirian, S.; Kalhor, E. Forecasting contractor's deviation from the client objectives in prequalification model using support vector regression. Int. J. Proj. Manag. 2013, 31, 924-936. [CrossRef]

63. Ulubeyli, S.; Kazaz, A. Fuzzy multi-criteria decision-making model for subcontractor selection in international construction projects. Technol. Econ. Dev. Econ. 2016, 22, 210-234. [CrossRef]

64. Semaan, N.; Salem, M. A deterministic contractor selection decision support system for competitive bidding. Eng. Constr. Archit. Manag. 2017, 24, 61-77. [CrossRef]

65. Afshar, M.R.; Alipouri, Y.; Sebt, M.H.; Chan, W.T. A type-2 fuzzy set model for contractor prequalification. Autom. Constr. 2017, 84, 356-366. [CrossRef] 
66. Martin, H.; Koylass, J.; Welch, F. An exploration of the consistency limits of the analytical hierarchy process and its impact on contractor selection. Int. J. Constr. Manag. 2018, 18, 14-25. [CrossRef]

67. Hashemi, H.; Mousavi, S.M.; Zavadskas, E.K.; Chalekaee, A.; Turskis, Z. A new group decision model based on grey-intuitionistic fuzzy-ELECTRE and VIKOR for contractor assessment problem. Sustainability 2018, 10, 1635. [CrossRef]

68. Cheng, M.-Y.; Yeh, S.-H.; Chang, W.-C. Multi-Criteria Decision Making of Contractor Selection in Mass Rapid Transit Station Development Using Bayesian Fuzzy Prospect Model. Sustainability 2020, 12, 4606. [CrossRef]

69. Triantaphyllou, E. Conclusions and Discussion for Future Research. In Multi-Criteria Decision-Making Methods: A Comparative Study; Applied Optimization; Springer: Boston, MA, USA, 2000; Volume 44. [CrossRef]

70. Mi, X.; Tang, M.; Liao, H.; Shen, W.; Lev, B. The state-of-the-art survey on integrations and applications of the best worst method in decision making: Why, what, what for and what's next? Omega 2019, 87, 205-225. [CrossRef]

71. Amiri, M.; Hashemi-Tabatabaei, M.; Ghahremanloo, M.; Keshavarz-Ghorabaee, M.; Zavadskas, E.K.; Antucheviciene, J. A new fuzzy approach based on BWM and fuzzy preference programming for hospital performance evaluation: A case study. Appl. Soft Comput. 2020, 92, 106279. [CrossRef]

72. Hendiani, S.; Mahmoudi, A.; Liao, H. A multi-stage multi-criteria hierarchical decision-making approach for sustainable supplier selection. Appl. Soft Comput. 2020, 94, 106456. [CrossRef]

73. Li, H.; Wang, W.; Fan, L.; Li, Q.; Chen, X. A novel hybrid MCDM model for machine tool selection using fuzzy DEMATEL, entropy weighting and later defuzzification VIKOR. Appl. Soft Comput. 2020, 91, 106207. [CrossRef]

74. Yue, C. Picture fuzzy normalized projection and extended VIKOR approach to software reliability assessment. Appl. Soft Comput. 2020, 88, 106056. [CrossRef]

75. Khoso, A.R.; Md Yusof, A. Extended review on contractor selection in construction projects. Can. J. Civ. Eng. 2019, 47, 771-789. [CrossRef]

76. Zimmermann, H.-J. Fuzzy Set Theory—and Its Applications; Springer Science \& Business Media: Berlin, Germany, 2001.

77. Birjandi, A.K.; Akhyani, F.; Sheikh, R.; Sana, S.S. Evaluation and selecting the contractor in bidding with incomplete information using MCGDM method. Soft Comput. 2019, 23, 10569-10585. [CrossRef]

78. $\mathrm{Wu}, \mathrm{Z}$;; Ahmad, J.; Xu, J. A group decision making framework based on fuzzy VIKOR approach for machine tool selection with linguistic information. Appl. Soft Comput. 2016, 42, 314-324. [CrossRef]

79. Guo, S.; Zhao, H. Fuzzy best-worst multi-criteria decision-making method and its applications. Knowl. -Based Syst. 2017, 121, 23-31. [CrossRef]

80. Chen, S.-J.; Hwang, C.-L. Fuzzy multiple attribute decision making methods. In Fuzzy Multiple Attribute Decision Making; Springer: Berlin, Germany, 1992; pp. 289-486.

81. Tzeng, G.-H.; Huang, J.-J. Fuzzy Multiple Objective Decision Making; CRC Press: Boca Raton, FL, USA, 2013.

82. Tian, Z.-p.; Wang, J.-q.; Zhang, H.-y. An integrated approach for failure mode and effects analysis based on fuzzy best-worst, relative entropy, and VIKOR methods. Appl. Soft Comput. 2018, 72, 636-646. [CrossRef]

83. Rezaei, J.; Papakonstantinou, A.; Tavasszy, L.; Pesch, U.; Kana, A. Sustainable product-package design in a food supply chain: A multi-criteria life cycle approach. Packag. Technol. Sci. 2019, 32, 85-101. [CrossRef]

84. Rezaei, J. Best-worst multi-criteria decision-making method: Some properties and a linear model. Omega 2016, 64, 126-130. [CrossRef]

85. Liang, F.; Brunelli, M.; Rezaei, J. Consistency issues in the best worst method: Measurements and thresholds. Omega 2020, 96, 102175. [CrossRef]

86. Saaty, T.L.; Özdemir, M.S. How many judges should there be in a group? Ann. Data Sci. 2014, 1, 359-368. [CrossRef]

87. Opricovic, S.; Tzeng, G.H. Multicriteria planning of post-earthquake sustainable reconstruction. Comput. -Aided Civ. Infrastruct. Eng. 2002, 17, 211-220. [CrossRef]

88. Tzeng, G.-H.; Tsaur, S.-H.; Laiw, Y.-D.; Opricovic, S. Multicriteria analysis of environmental quality in Taipei: Public preferences and improvement strategies. J. Environ. Manag. 2002, 65, 109-120. [CrossRef] [PubMed] 